Check for updates

Cite this: RSC Adv., 2019, 9, 37986

Received 29th September 2019 Accepted 7th November 2019

DOI: $10.1039 / c 9 r a 07912 b$

rsc.li/rsc-advances

\section{Synthesis of new Pro-PYE ligands as co-catalysts toward Pd-catalyzed Heck-Mizoroki cross coupling reactions $\dagger$}

\author{
Naima Munir, ${ }^{\text {a }}$ Sara Masood, ${ }^{a}$ Faroha Liaqat, ${ }^{a}$ Muhammad Nawaz Tahir, ${ }^{b}$ \\ Sammer Yousuf, ${ }^{c}$ Saima Kalsoom, ${ }^{d}$ Ehsan Ullah Mughal, ${ }^{e}$ Sajjad Hussain Sumrra, ${ }^{e}$ \\ Aneela Maalik (D) *f and Muhammad Naveed Zafar*a
}

The present research work describes the synthesis of five new ligands containing pyridinium amine, $\left[\mathrm{H}_{2} \mathrm{~L}^{1}\right]$ $[\mathrm{OTf}]_{2}-\left[\mathrm{H}_{2} \mathrm{~L}^{5}\right][\mathrm{I}]_{2}$ from two new precursors, $\left[\mathrm{P}^{3} \mathrm{Et}\right][\mathrm{I}]$ and $\left[\mathrm{P}^{2} \mathrm{Me}_{\mathrm{e}}\right]\left[\mathrm{CF}_{3} \mathrm{SO}_{3}\right]$. The structure elucidations of the compounds were confirmed by multinuclear NMR $\left({ }^{1} \mathrm{H},{ }^{13} \mathrm{C}\right), \mathrm{FT}-\mathrm{IR}$ and by single crystal XRD techniques. Theoretical DFT studies were carried out to get better insight into the electronic levels and structural features of all the molecules. These synthesized new Pro-PYE ligands $\left[\mathrm{H}_{2} \mathrm{~L}^{1}\right][\mathrm{OTf}]_{2}-\left[\mathrm{H}_{2} \mathrm{~L}^{5}\right][\mathrm{I}]_{2}$ were found to be significantly active as co-catalysts for $\mathrm{Pd}\left(\mathrm{CH}_{3} \mathrm{CO}_{2}\right)_{2}$ toward Heck-Mizoroki coupling reactions with wide substrate scope in the order of $\left[\mathrm{H}_{2} \mathrm{~L}^{1}\right][\mathrm{OTf}]_{2} \gg\left[\mathrm{H}_{2} \mathrm{~L}^{2}\right][\mathrm{OTf}]_{2}>\left[\mathrm{H}_{2} \mathrm{~L}^{3}\right][\mathrm{OTf}]_{2}>\left[\mathrm{H}_{2} \mathrm{~L}^{4}\right][\mathrm{OTf}]_{2}>\left[\mathrm{H}_{2} \mathrm{~L}^{5}\right][]_{2}$.

\section{Introduction}

Electron donor ligands are essential for those metals undergoing various oxidative addition reactions. Phosphines and $\mathrm{N}$ heterocyclic carbene (NHC) ligands are prevalent in this scenario owing to their remarkable electron donor characteristics. ${ }^{1-3}$ The steric hindrance of a substituted $\mathrm{R}$ group towards the metal in NHCs facilitates reductive elimination and product selectivity that mark this ligand as a superior choice in homogeneous catalysis, especially in cross-coupling chemistry. ${ }^{4-7}$ In depth study reveals that the tuning of the electronic density of a ligand is desirable according to the requirement of a coordinated metal to catalyze various stages of the redox process. ${ }^{\mathbf{8} 9}$ Therefore the non-innocent ligands are ideally suited for this type of chemistry as they have the ability to switch and stabilize the various oxidation states of metals during chemical transformations. ${ }^{\mathbf{1 0}-12}$ These ligands are promising in the field of catalysis as they are redox active spectator ligands. They not only block few coordination sites of the metal but

\footnotetext{
${ }^{a}$ Department of Chemistry, Quaid-i-Azam University, Islamabad-45320, Pakistan. E-mail: mnzafar@qau.edu.pk; Tel: +923314503061

${ }^{b}$ Department of Physics, University of Sargodha, Sargodha-40100, Pakistan

${ }^{c} H$. E. J. Research Institute of Chemistry, International Centre for Chemical and Biological Sciences, University of Karachi, 75270, Pakistan

${ }^{d}$ Centre for Interdisciplinary Research in Basic Sciences (CIRBS), International Islamic University, Islamabad, Pakistan

${ }^{e}$ Department of Chemistry, University of Gujrat, Gujrat-50700, Pakistan ${ }^{f}$ Department of Chemistry, COMSATS University Islamabad, Islamabad Campus, Park Road, Islamabad-45550, Pakistan. E-mail: aneela.maalik@comsats.edu.pk; Tel: +923335490834

$\dagger$ Electronic supplementary information (ESI) available. CCDC 1955342, 1955343, 1955344, 1955349 and 1961686. For ESI and crystallographic data in CIF or other electronic format see DOI: 10.1039/c9ra07912b
}

also serve as electron reservoirs. ${ }^{\mathbf{1 3 , 1 4}}$ Anionic ligand in resonance with cationic moiety can generate this kind of ligand. For example $N$-(1-methylpyridin-4(1H)-ylidene) amine (PYE) is a type of neutral nitrogen donor ligand that possesses electronic density adaptable to the requirement of metal owing to its resonance structures with varying charge on nitrogen from uni-negative to neutral (Fig. 1). ${ }^{15}$ The additional feature includes the exocyclic nitrogen atom of PYE that is pointed towards metal to control its steric environment. ${ }^{\mathbf{1 6 - 1 8}}$

The catalytic cycle of Heck-Mizoroki C-C cross coupling involves both oxidative addition as well as reductive elimination reaction. This coupling method is an appropriate synthetic route for synthesis of substituted olefins. High electronic density around the palladium via appropriate electron rich ligand facilitates oxidative addition (the key rate determining step) of various aliphatic or aromatic halides in the coupling reaction. ${ }^{19-21}$ Various palladium complexes have been used to catalyze above reaction. ${ }^{22-24}$ However, the much easier way is to use a mixture of suitable ligand and palladium precursor. ${ }^{25,26}$ In this regard, five new H-PYE ligands, $\left[\mathrm{H}_{2} \mathrm{~L}^{1}\right][\mathrm{OTf}]_{2}-\left[\mathrm{H}_{2} \mathrm{~L}^{5}\right][\mathrm{I}]_{2}$, were synthesized (Schemes 1-3) from two ligand precursors $\left[\mathrm{P}^{3}{ }_{\mathrm{Et}}\right][\mathrm{I}]$ and $\left[\mathrm{P}^{2}{ }_{\mathrm{Me}}\right]\left[\mathrm{CF}_{3} \mathrm{SO}_{3}\right]$. These ligands were found to act as co-catalysts for $\mathrm{Pd}(\mathrm{OAc})_{2}$ and significantly enhanced their catalytic activity in Mizoroki-Heck coupling reactions under diverse reaction conditions. The molecular structures of all new compounds were characterized by using various spectroscopic and computational techniques.

\section{Experimental}

\subsection{Reagents}

Methyl triflate, 2-chloropyridine, cyclohexane-1,2-diamine, pyridine-2,6-diamine, ethane-1,2-diamine, aryl halides, ethyl 


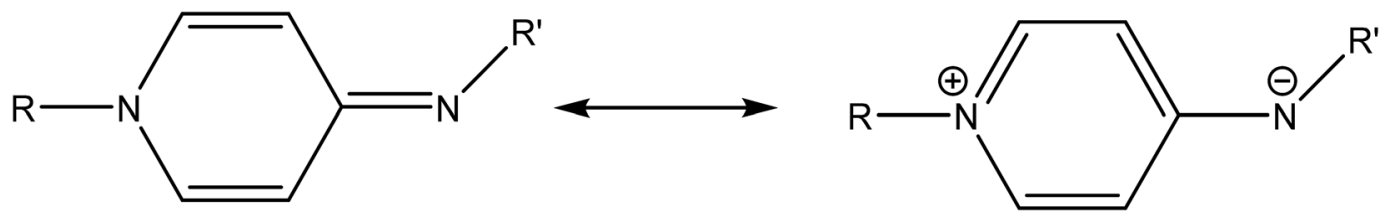

Fig. 1 Possible resonance in PYE.

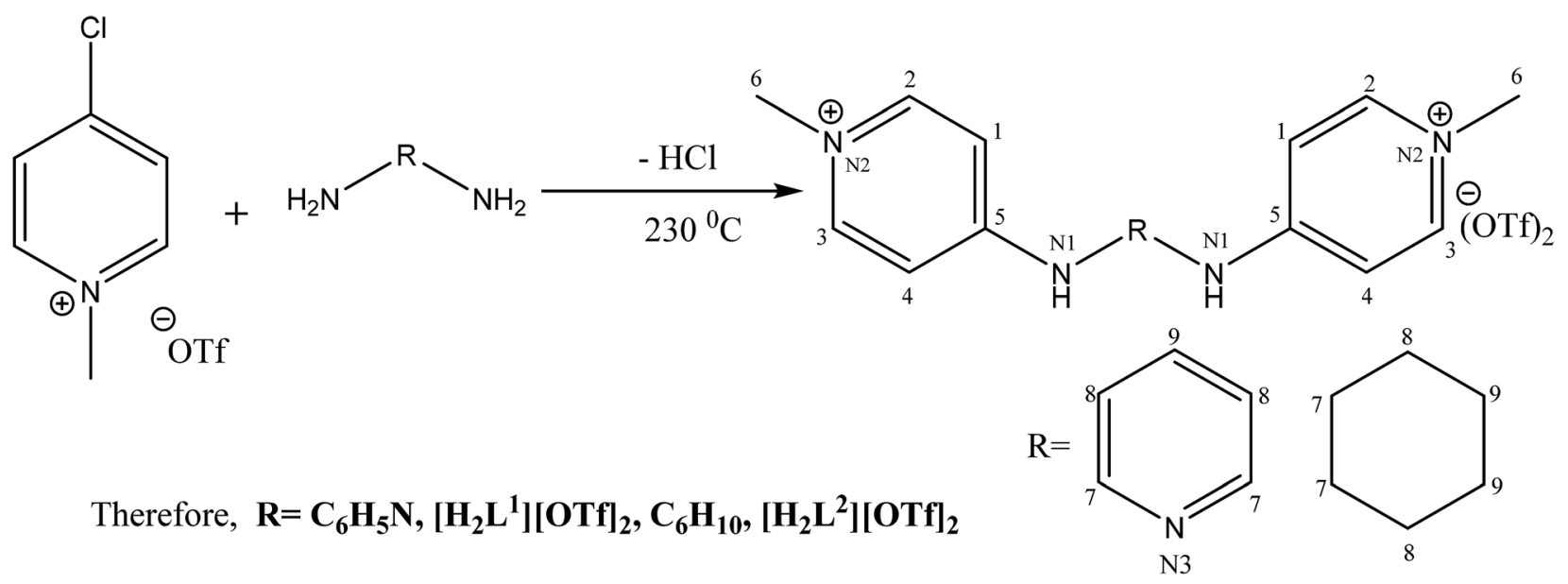

Scheme 1 Synthesis of $\left[\mathrm{H}_{2} \mathrm{~L}^{1}\right][\mathrm{OTf}]_{2}$ and $\left[\mathrm{H}_{2} \mathrm{~L}^{2}\right][\mathrm{OTf}]_{2}$.

acrylate and styrene purchased from Sigma Aldrich were used. Solvents were dried using standard procedures. $N$-Methyl-4chloropyridinium triflate was synthesized by the reported method. ${ }^{27}$

\subsection{Apparatus and instruments used}

All reactions were performed under inert environment by Schlenk line technique. Melting point analysis was performed on Shimadzu melting point apparatus. Thermo Scientific spectrometer ranges from $4000-400 \mathrm{~cm}^{-1}$ was used to record FT-IR spectras. NMR spectra were recorded by using Bruker Avance Digital $300 \mathrm{MHz}\left({ }^{1} \mathrm{H}\right)$ and $75 \mathrm{MHz}\left({ }^{13} \mathrm{C}\right)$ at $300 \mathrm{~K}$ in DMSO- $d_{6}$.

\subsection{Chemistry}

Syntheses of seven new compounds were shown in Schemes 1-3.

2.3.1. Synthesis of $\left[\mathbf{P}^{3} \mathbf{E t}\right][\mathbf{I}]$ (1). 2-Iodopyridinium ethyl iodide was prepared by treating 2-chloropyridine $(4.91 \mathrm{~mL}$, $53 \mathrm{mmol}, 1$ eq.) with ethyl iodide $(12.78 \mathrm{~mL}, 159 \mathrm{mmol}, 3$ eq. $)$ in three neck round bottom flask $(250 \mathrm{~mL})$. Dichloromethane was also subjected to flask. The resulted mixture was subjected to heat under water bath for 12 hours. The product was cooled and washed by subsequent addition of acetone and pure product was achieved.

Royal yellow solid, yield 56\%, mp: $156{ }^{\circ} \mathrm{C} .{ }^{1} \mathrm{H}$ NMR $(300 \mathrm{MHz}$, DMSO- $\left.d_{6}\right), J(\mathrm{~Hz}), \delta(\mathrm{ppm}): 9.28(\mathrm{dd}, 1 \mathrm{H}, J=1.8, P y-H), 8.65$ (dd, $1 \mathrm{H}, J=1.8, P y-H), 8.19-8.07(\mathrm{~m}, 2 \mathrm{H}, P y-H), 4.75$ (q, 2H, $J=7.2$, $\mathrm{CH}_{2}$ ), 1.49 (t, 3H, $\left.J=7.2, \mathrm{CH}_{3}\right) .{ }^{13} \mathrm{C}$ NMR (75 MHz, DMSO- $\left.d_{6}\right), J$ $(\mathrm{Hz}), \delta$ (ppm): 147.5, 144.7, 141.21, 127.87, 122.60, 62.31, 15.96. FT-IR (KBr, cm ${ }^{-1}$ ): 3069, 2956, 1600, 1357, 1272, 1153, 1065.
2.3.2. Synthesis of $\left[\mathbf{P}^{2}{ }_{M e}\right]\left[\mathrm{CF}_{3} \mathbf{S O}_{3}\right]$ (2). $N$-(1-Methylpyridin$2(1 H)$-ylidene) amine was synthesised by treating 2-chloropyridine ( 1 eq., $1.5 \mathrm{~mL}, 15.85 \mathrm{mmol}$ ) with methyl triflate (1.2 eq., $2.0 \mathrm{~mL}, 19.02 \mathrm{mmol}$ ) in DCM. After overnight stirring, the solvent was evaporated and product was precipitated out by addition of ether.

Colorless solid, yield 95\%, mp: $161{ }^{\circ} \mathrm{C} .{ }^{1} \mathrm{H}$ NMR $(300 \mathrm{MHz}$, DMSO- $\left.d_{6}\right), J(\mathrm{~Hz}), \delta(\mathrm{ppm}): 9.16(\mathrm{dd}, 1 \mathrm{H}, J=1.5, P y-H), 8.62-8.56$ (m, 1H, $P y-H), 8.37$ (dd, 1H, $P y-H), 8.12-8.07$ (m, 1H, Py-H) 4.33 $\left(\mathrm{s}, 3 \mathrm{H}, \mathrm{CH}_{3}\right) .{ }^{13} \mathrm{C}$ NMR (75 MHz, DMSO- $\left.d_{6}\right), J(\mathrm{~Hz}), \delta(\mathrm{ppm})$ : 148.6, 147.4, 129.9, 126.5, 123.2, 119.0, 47.8. FT-IR (KBr, $\left.\mathrm{cm}^{-1}\right)$ : 3097, 1617, 1309, 1260, 1142, 1028.

2.3.3. Synthesis of $\left[\mathrm{H}_{2} \mathbf{L}^{1}\right][\mathrm{OTf}]_{2}-\left[\mathrm{H}_{2} \mathbf{L}^{5}\right][\mathbf{I}]_{2}(3-7)$

$\left[\mathrm{H}_{2} \mathrm{~L}^{1}\right]\left[\mathrm{CF}_{3} \mathrm{SO}_{3}\right]_{2}$ (3). $\mathrm{N}$-methylated-4-chloropyridinium triflate $(0.5 \mathrm{~g}, 1.8 \mathrm{mmol}, 2 \mathrm{eq}$.) and pyridine diamine $(0.1 \mathrm{~g}, 0.9 \mathrm{mmol}, 1$ eq.) was subjected into two neck flask $(100 \mathrm{~mL})$. An argon atmosphere was provided to reaction mixture. The reaction was heated for about 3 hours at $230{ }^{\circ} \mathrm{C}$. After the completion of reaction, solid was cooled to ambient temperature and scratched by spatula from flask. The off white crystals were dried in vacuo to give pure product. The crystals were grown in mixture of solvents as methanol and acetone.

Off white solid, yield 70\%, mp: $165{ }^{\circ} \mathrm{C} .{ }^{1} \mathrm{H}$ NMR $(300 \mathrm{MHz}$, DMSO- $\left.d_{6}\right), J(\mathrm{~Hz}), \delta(\mathrm{ppm}): 11.06(\mathrm{~s}, 2 \mathrm{H}, N H), 8.48-8.46(\mathrm{~d}, 4 \mathrm{H}, J$ $=7.2, p y-H), 7.96-7.91(\mathrm{~d}, 1 \mathrm{H}, J=7.7, p y-H), 7.84-7.82(\mathrm{~d}, 4 \mathrm{H}, J$ $=6.3, p y-H), 6.96-6.94(\mathrm{~d}, 2 \mathrm{H}, J=8.1, p y-H), 4.07(\mathrm{~s}, 6 \mathrm{H}$, $\left.\mathrm{CH}_{3}\right) .{ }^{13} \mathrm{C}$ NMR (75 MHz, DMSO- $\left.d_{6}\right), J(\mathrm{~Hz}), \delta(\mathrm{ppm}): 152.6,151.1$, 145.1, 143.2, 112.9, 109.7, 45.8. FT-IR (KBR, $\left.\mathrm{cm}^{-1}\right)$ : 3296, 3080, 1638, 1581, 1365, 1278, 1199, 1025.

$\left[\mathrm{H}_{2} \mathrm{~L}^{2}\right]\left[\mathrm{CF}_{3} \mathrm{SO}_{3}\right]_{2}$ (4). $\mathrm{N}$-methylated-4-chloropyridinium triflate $(1 \mathrm{~g}, 3.6 \mathrm{mmol}, 2 \mathrm{eq}$.) along with cyclohexane diamine $(0.21 \mathrm{~mL}$, 

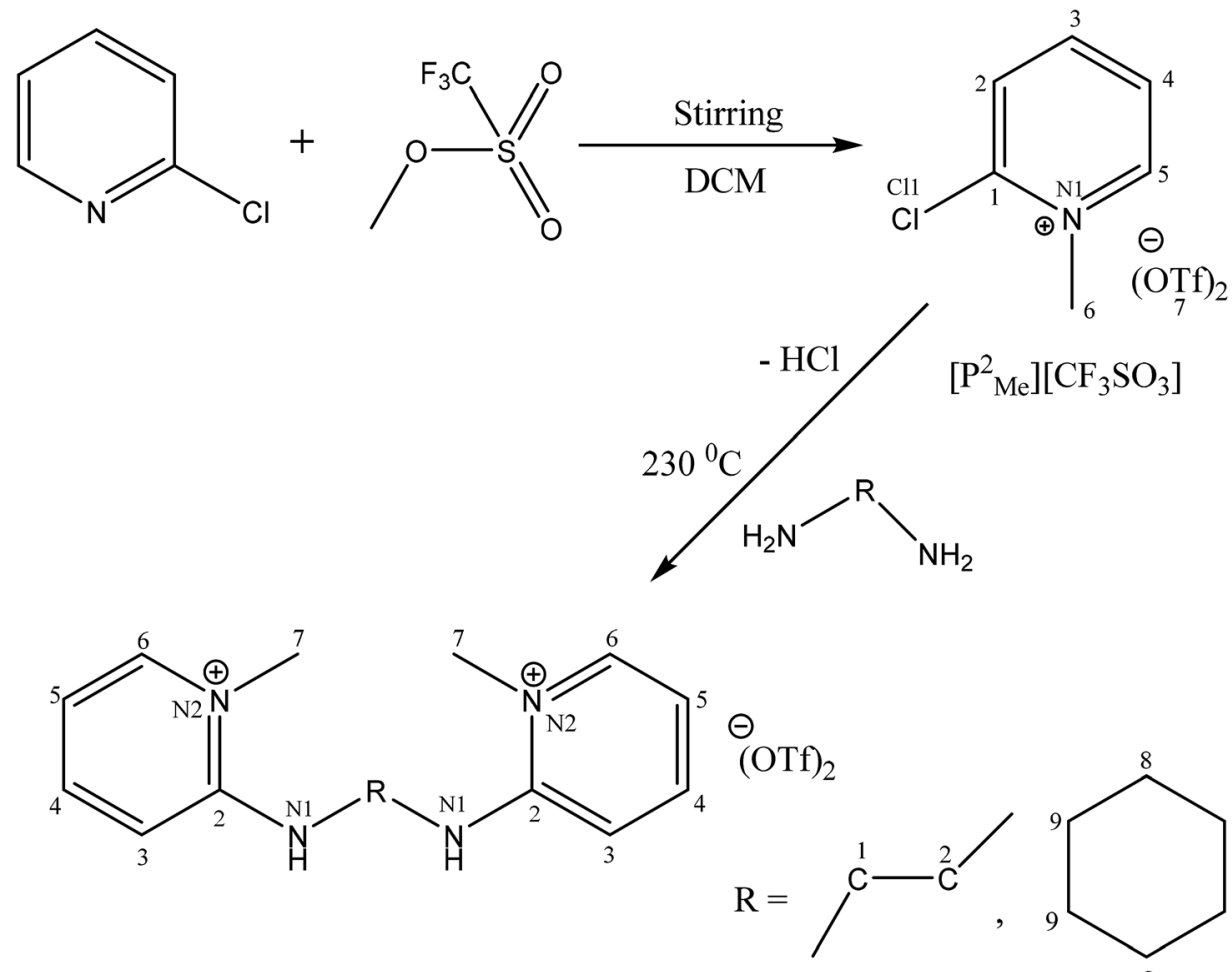

Therefore, $\mathbf{R}=\mathbf{C}_{6} \mathbf{H}_{10},\left[\mathrm{H}_{2} \mathrm{~L}^{3}\right][\mathrm{OTf}]_{2}, \mathbf{C}_{\mathbf{2}} \mathrm{H}_{\mathbf{4}},\left[\mathrm{H}_{2} \mathbf{L}^{4}\right][\mathrm{OTf}]_{2}$

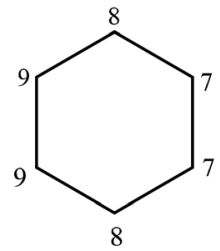

Scheme 2 Synthesis of $\left[\mathrm{H}_{2} \mathrm{~L}^{3}\right][\mathrm{OTf}]_{2}$ and $\left[\mathrm{H}_{2} \mathrm{~L}^{4}\right][\mathrm{OTf}]_{2}$.

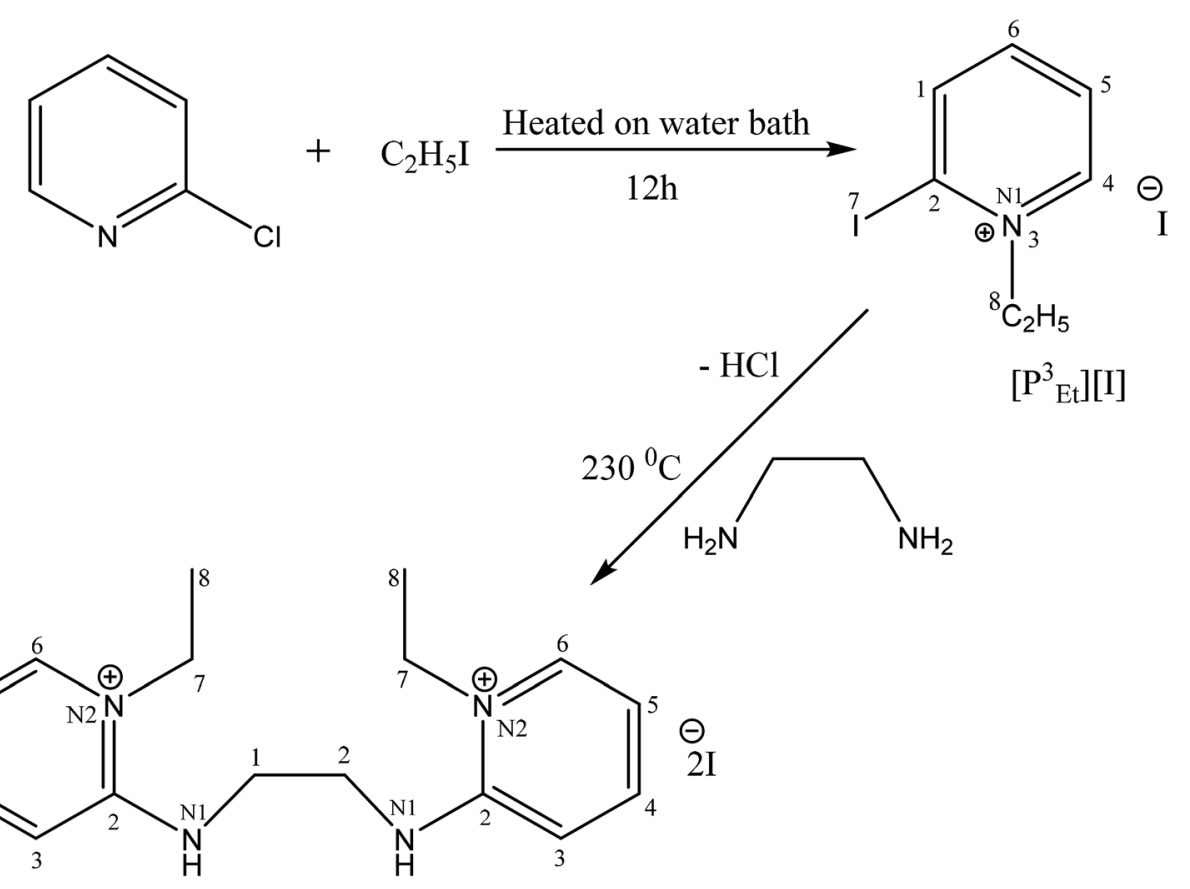

$\left[\mathrm{H}_{2} \mathbf{L}^{5}\right]\left[\mathrm{I}_{2}\right.$

Scheme 3 Synthesis of $\left[\mathrm{H}_{2} \mathrm{~L}^{5}\right][]_{2}$. 
$1.8 \mathrm{mmol}, 1$ eq.) were added in two necked round bottom flask $(50 \mathrm{~mL})$. Under argon the temperature was provided to reaction mixture for about 150 minutes at $230{ }^{\circ} \mathrm{C}$. The solid was cooled and recrystallised from methanol and acetone and dried in vacuo to give pure product $\left[\mathrm{H}_{2} \mathrm{~L}^{1}\right][\mathrm{OTf}]_{2}$.

Brown crystalline solid, yield 78\%, mp: $180{ }^{\circ} \mathrm{C} .{ }^{1} \mathrm{H}$ NMR $(300$ MHz, DMSO- $\left.d_{6}\right), J(\mathrm{~Hz}), \delta(\mathrm{ppm}): 9.11(\mathrm{~s}, 2 \mathrm{H}, N H), 8.18-8.15(\mathrm{~d}$, $2 \mathrm{H}, J=6.9, p y-H), 7.93-7.91(\mathrm{~d}, 2 \mathrm{H}, J=6.9, p y-H), 7.21-7.19(\mathrm{~m}$, 2H, py-H), 6.75-6.73 (m, 2H,py-H), $3.81\left(\mathrm{~s}, 6 \mathrm{H}, \mathrm{CH}_{3}\right), 3.71-3.69$ $(\mathrm{d}, 2 \mathrm{H}, J=6, c y-H), 1.75-1.73(\mathrm{~d}, 2 \mathrm{H}, J=7.8, c y-H), 1.53-1.49$ (d, $2 \mathrm{H}, J=9.3, c y-H), 1.45-1.37(\mathrm{~m}, 4 \mathrm{H}, c y-H) .{ }^{13} \mathrm{C}$ NMR $(75 \mathrm{MHz}$, DMSO- $\left.d_{6}\right), J(\mathrm{~Hz}), \delta(\mathrm{ppm}): 156.5,144.3,142.5,110.4,106.3,56.2$, 44.4, 31.5, 24.3. IR (KBR, $\mathrm{cm}^{-1}$ ): 3360, 3053, 2943, 1646, 1588, 1375, 1296, 1169, 1058.

$\left[\mathrm{H}_{2} \mathrm{~L}^{3}\right]\left[\mathrm{CF}_{3} \mathrm{SO}_{3}\right]_{2}$ (5). 2-Chloropyridinium methyl triflate $(0.5 \mathrm{~g}$, $1.8 \mathrm{mmol}, 2 \mathrm{eq}$.) was added in a vacuum dried two neck round bottom flask $(50 \mathrm{~mL})$. Cyclohexane diamine $(0.1 \mathrm{~mL}, 0.9 \mathrm{mmol} 1$ eq.) was introduced by glass syringe $(100 \mu \mathrm{L})$ under argon into the flask. Then reaction mixture was heated for about 3 hours. Thermometer was used to monitor the temperature. After the completion of reaction, product was cooled to room temperature and scratched from the flask carefully via spatula. Desiccator was used to dry the solid. Good quality crystals can be grown in mixture of acetone and methanol.

Brown solid, yield 60\%, mp: $232{ }^{\circ} \mathrm{C} .{ }^{1} \mathrm{H}$ NMR $(300 \mathrm{MHz}$, DMSO- $\left.d_{6}\right), J(\mathrm{~Hz}), \delta(\mathrm{ppm}): 8.26(\mathrm{t}, 2 \mathrm{H}, J=6.6, N H), 8.24-8.18(\mathrm{dd}$, $2 \mathrm{H}, J=6.9, p y-H), 7.99-7.37(\mathrm{~m}, 2 \mathrm{H}, p y-H), 7.03-7.00(\mathrm{~d}, 1 \mathrm{H}, J=$ 7.5, py-H), 6.53-6.45 (dd, $1 \mathrm{H}, J=8.4, p y-H), 3.99\left(\mathrm{~s}, \mathrm{CH}_{3}, 6 \mathrm{H}\right)$, $3.66(\mathrm{~s}, 1 \mathrm{H}, c y-H), 3.54-3.50(\mathrm{~d}, 1 \mathrm{H}, J=3.6, c y-H), 2.49-2.25(\mathrm{~m}$, $2 \mathrm{H}, c y-H), 1.88-1.86(\mathrm{~d}, 2 \mathrm{H}, J=6 c y-H), 1.66-1.65$ (d, 2H, $J=3$, $c y-H), 1.19-1.17(\mathrm{~d}, 2 \mathrm{H}, J=5.1, c y-H) .{ }^{13} \mathrm{C}$ NMR (75 MHz, DMSO$\left.d_{6}\right), J(\mathrm{~Hz}), \delta(\mathrm{ppm}): 159.1,153.3,147.7,143.2,112.7,43.2,32.8$, 24.5.

$\left[\mathrm{H}_{2} \mathrm{~L}^{4}\right]\left[\mathrm{CF}_{3} \mathrm{SO}_{3}\right]_{2}$ (6). Ethylene diamine $(240.1 \mu \mathrm{L}, 3.60 \mathrm{mmol})$ and $N$-methylated-2-chloropyridinium triflate $(2 \mathrm{~g}, 7.2 \mathrm{mmol})$ were added in a $50 \mathrm{~mL}$ two neck round bottom flask under inert atmosphere and flask was heated for 2 hours at $180{ }^{\circ} \mathrm{C}$. During this time, the solid reactant melts and undergoes melt reaction. After that time the melt was cooled to room temperature and the solid scratched from the flask. The solid was recrystallized from methanol to give pure dark brown crystalline product.

Dark brown solid, yield 70\%; mp: $205{ }^{\circ} \mathrm{C} .{ }^{1} \mathrm{H}$ NMR $(300 \mathrm{MHz}$, DMSO- $\left.d_{6}\right), J(\mathrm{~Hz}), \delta(\mathrm{ppm}): 8.28(\mathrm{t}, 2 \mathrm{H}, J=5.7, N H), 8.09-8.03(\mathrm{~m}$, $4 \mathrm{H}, P y-H), 7.42-7.39$ (d, $4 \mathrm{H}, J=9, P y-H), 7.05-6.99$ (m, 2H, $P y-H)$, $3.79\left(\mathrm{~d}, 6 \mathrm{H}, \mathrm{J}=4.8, \mathrm{CH}_{3}\right), 3.67\left(\mathrm{~d}, 4 \mathrm{H}, \mathrm{J}=4.5, \mathrm{CH}_{2}\right) .{ }^{13} \mathrm{C} \mathrm{NMR}(75$ MHz, DMSO- $\left.d_{6}\right), J(\mathrm{~Hz}), \delta(\mathrm{ppm}): 153.2,143.5,142.4,123.3,118.9$, 113.2, 111.5, 42.2, 40.7. IR (KBr, $\left.\mathrm{cm}^{-1}\right): 3325,3086,2952,1649$, 1591, 1348, 1243, 1159, 1025.

$\left[\mathrm{H}_{2} \mathrm{~L}^{5}\right][\mathrm{I}]_{2}$ (7). 2-Iodo-1-ethyl-pyridinium iodide $(0.2 \mathrm{~g}$, $4.2 \mathrm{mmol}, 2$ eq.) was added in two necks round bottom flask. The flask was charged with ethylene diamine $(0.138 \mathrm{~mL}$, $2.07 \mathrm{mmol}, 1$ eq.) and potassium carbonate $\left(\mathrm{K}_{2} \mathrm{CO}_{3}\right)(1.7 \mathrm{~g}$, $12.46 \mathrm{mmol}, 6$ eq.) under inert argon. The mixture was stirred and refluxed in dichloromethane (DCM) for 20 hours at $80{ }^{\circ} \mathrm{C}$. After refluxing, volatiles were removed. The product was recrystallized in DCM, collected and dried in vacuo to give pure product of orange yellow color.
Fawn yellow solid, yield 48\%; mp: $304{ }^{\circ} \mathrm{C} .{ }^{1} \mathrm{H}$ NMR $(300 \mathrm{MHz}$, DMSO- $\left.d_{6}\right), J(\mathrm{~Hz}), \delta(\mathrm{ppm}): 8.28(\mathrm{~s}, 1 \mathrm{H}, N-H), 8.19$ (s, 1H, Py-H), 8.04 (s, 1H, $P y-H), 7.40$ (d, 1H, $P y-H), 7.03$ (s, 1H, $P y-H), 4.22$ (q, $\left.2 \mathrm{H}, J=5.1, \mathrm{CH}_{2}\right), 3.68\left(\mathrm{~s}, 2 \mathrm{H}, \mathrm{CH}_{2}\right), 1.31\left(\mathrm{t}, 3 \mathrm{H}, J=7.2, \mathrm{CH}_{3}\right) . \mathrm{IR}$ $\left(\mathrm{KBr}, \mathrm{cm}^{-1}\right): 3205,3016,2970,1642,1536,1364,1217,1173$, 1063.

2.3.4. General method for the heck-coupling reaction. A dried evacuated tube $(20 \mathrm{~mL})$ fitted with Teflon tap was charged with $\mathrm{Pd}(\mathrm{OAc})_{2}(4.0 \mu \mathrm{mol}, 0.01)$, ligand $(4.0 \mu \mathrm{mol}, 0.01)$, sodium acetate (1.1 eq., $440 \mu \mathrm{mol}, 36 \mathrm{mg}$ ), magnetic stirrer under inert environment. Styrene (1.4 eq., $64 \mu \mathrm{L}, 560 \mu \mathrm{mol})$, halobenzene (1.0 eq., $42 \mu \mathrm{L}, 400 \mathrm{mmol}$ ) and dry DMA ( $2 \mathrm{~mL}$ ) were added to the flask which was heated first at $\left(130^{\circ} \mathrm{C}\right)$ for 3 hours and then cooled to room temperature before use. On completion, the reaction flask was cooled at ambient temperature. After cooling, the mixture was extracted with ethyl acetate/n-hexane $(1: 5)$ solution. Column chromatography was employed to purify the product using ethyl acetate/n-hexane $(20: 80)$. Multinuclear NMR spectroscopy $\left({ }^{1} \mathrm{H}\right.$ NMR) confirmed the formation of product.

\section{Results and discussion}

\subsection{Synthesis and characterization}

The $\mathrm{N}$-alkylation of 2-chloropyridine was carried out with ethyl iodide and methyl triflate to synthesize ligand precursors. Ethyl iodide being weak alkylating agent than methyl triflate required more vigorous conditions to yield $\left[\mathrm{P}^{3}{ }_{\mathrm{Et}}\right][\mathrm{I}]$ as compared to $\left[\mathrm{P}^{2}{ }_{\mathrm{Me}}\right]$ $\left[\mathrm{CF}_{3} \mathrm{SO}_{3}\right]$. During the synthesis of $\left[\mathrm{P}^{3}{ }_{\mathrm{Et}}\right][\mathrm{I}]$, chloro attached at alpha carbon was substituted by iodo group and also appeared as counter anion, upon heating in water bath for 12 hours. ${ }^{28,29}$ The ethylation on pyridine was suggested by a quartet and triplet peaks at 4.75 and $1.49 \mathrm{ppm}$ in proton NMR spectrum. The other ligand precursor, $\left[\mathrm{P}^{2}{ }_{\mathrm{Me}}\right]\left[\mathrm{CF}_{3} \mathrm{SO}_{3}\right]$ was synthesized by just overnight stirring of 2-chloropyridine with methyl triflate. The methyl peak appeared at 4.33, $47.8 \mathrm{ppm}$ in ${ }^{1} \mathrm{H}$ and ${ }^{13} \mathrm{C} \mathrm{NMR}$ spectra respectively. The IR spectra of precursors $\left[\mathrm{P}^{3}{ }_{\mathrm{Et}}\right][\mathrm{I}]-\left[\mathrm{P}^{2}{ }_{\mathrm{Me}}\right]$ $\left[\mathrm{CF}_{3} \mathrm{SO}_{3}\right]$ showed aromatic stretch $\nu(\mathrm{C}-\mathrm{H})$ at 3069-3085, aliphatic $\nu(\mathrm{C}-\mathrm{H})$ at $2956, \nu(\mathrm{C}=\mathrm{N})$ at $1562-1588 \mathrm{~cm}^{-1}, \nu(\mathrm{C}=\mathrm{C})$ at $1600-1646 \mathrm{~cm}^{-1}, \nu(\mathrm{C}-\mathrm{N})$ at $1357-1303 \mathrm{~cm}^{-1}, \nu(\mathrm{C}-\mathrm{I})$ at $445 \mathrm{~cm}^{-1}$, and $\nu(\mathrm{C}-\mathrm{Cl})$ band at $633 \mathrm{~cm}^{-1}$ respectively. All remaining peaks appeared in their respective regions.

All the ligands, $\left[\mathrm{H}_{2} \mathrm{~L}^{1}\right][\mathrm{OTf}]_{2}-\left[\mathrm{H}_{2} \mathrm{~L}^{5}\right][\mathrm{I}]_{2}$, were synthesised by the melt reaction between respective ligand precursor and corresponding amine. In these ligands, NH peak appeared in the range of 9-11 ppm that indicated the conversion of all primary amines to secondary amines. In aliphatic region, $N$-alkylated protons showed peaks for methyl and ethyl between 4.24$3.70 \mathrm{ppm}$ in all ligands. Similarly carbon NMR showed these peaks between 62.3-47.8 ppm. The aromatic protons and their carbon atoms showed the respective peaks in their standard region. The peaks for cyclohexyl group appeared between 1.17$3.71 \mathrm{ppm}$ for $\left[\mathrm{H}_{2} \mathrm{~L}^{2}\right][\mathrm{OTf}]_{2}$ and $\left[\mathrm{H}_{2} \mathrm{~L}^{3}\right][\mathrm{OTf}]_{2}$. In FT-IR spectra, the broad peaks appeared between 3296-3205 $\mathrm{cm}^{-1}$ for $\nu(\mathrm{N}-\mathrm{H})$. While peaks of $\delta(\mathrm{N}-\mathrm{H})$ appeared at $1581-1591 \mathrm{~cm}^{-1}$ in $\left[\mathrm{H}_{2} \mathrm{~L}^{1}\right]$ $[\mathrm{OTf}]_{2}-\left[\mathrm{H}_{2} \mathrm{~L}^{5}\right][\mathrm{I}]_{2}$. Peaks of aromatic region $\nu(\mathrm{C}-\mathrm{H})$ ranges $3101-$ $3016 \mathrm{~cm}^{-1}$ while skeleton vibrations or peaks due to breathing 

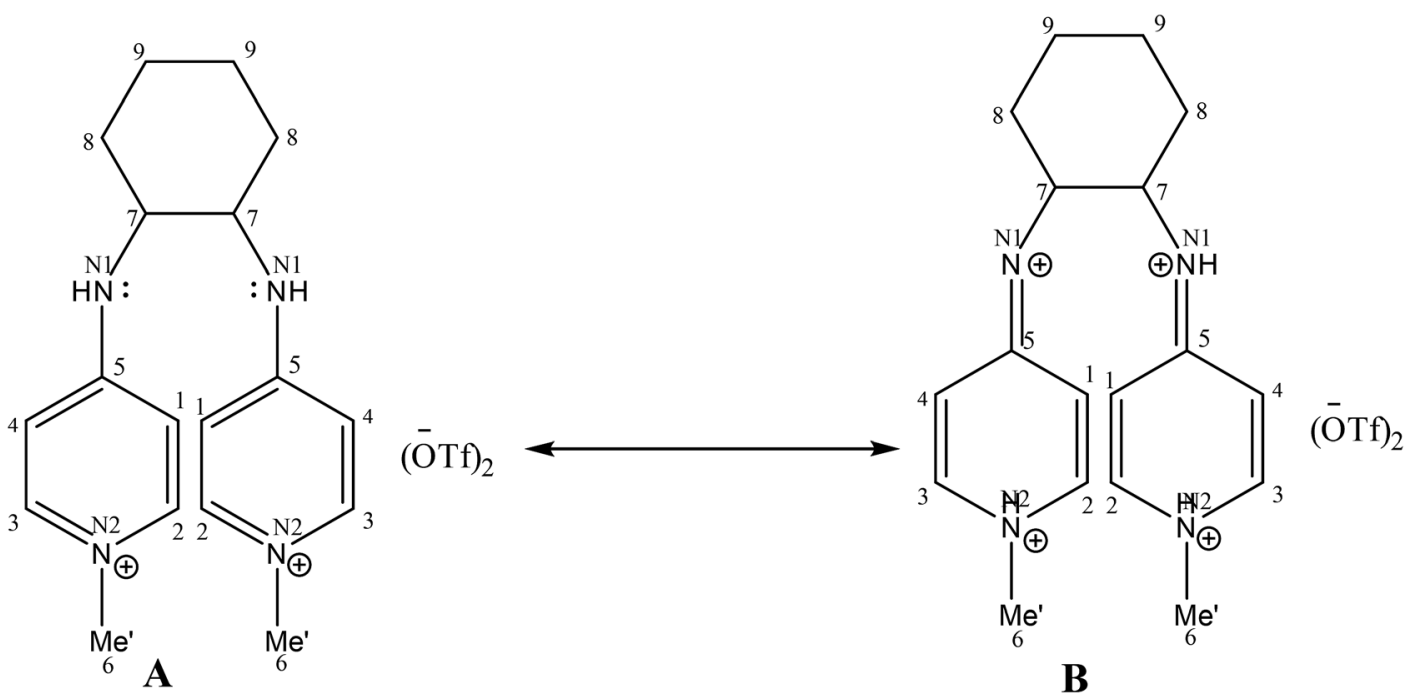

Fig. 2 Resonance forms of $\left[\mathrm{H}_{2} \mathrm{~L}^{2}\right][\mathrm{OTf}]_{2}$.

vibrations of aromatic ring were observed around the following frequencies; $1600,1560,1500,1460 \mathrm{~cm}^{-1} \cdot{ }^{30}$ In aliphatic region, the characteristic stretching band $\nu(\mathrm{C}-\mathrm{H})$ appeared at $2970-$ $2943 \mathrm{~cm}^{-1}$ and bending vibrations associated with $\delta(\mathrm{C}-\mathrm{H})$ present in the particular range of $1436-1459 \mathrm{~cm}^{-1}$. Signals appeared for both secondary $\mathrm{C}=\mathrm{N}$ and primary $\mathrm{C}-\mathrm{N}$ stretch in the region of $1690-1590 \mathrm{~cm}^{-1}$ and $1350-1280 \mathrm{~cm}^{-1}$ respectively. Peaks between $1350-1225 \mathrm{~cm}^{-1}$ were assigned to both asymmetric and symmetric $\nu(\mathrm{S}=\mathrm{O})$, while signals between 828$863 \mathrm{~cm}^{-1}$ were designated to $\nu(\mathrm{S}-\mathrm{O})$. Sharp peak associated with $\nu(\mathrm{C}-\mathrm{F})$ observed in the range of $1025-1063 \mathrm{~cm}^{-1}$.

A comparison of proton and carbon NMR spectra of $\left[\mathrm{H}_{2} \mathrm{~L}^{1}\right]$ $[\mathrm{OTf}]_{2}$ and $\left[\mathrm{H}_{2} \mathrm{~L}^{2}\right][\mathrm{OTf}]_{2}$ reveals that $\mathrm{B}$ type resonance structure is predominant for $\left[\mathrm{H}_{2} \mathrm{~L}^{2}\right][\mathrm{OTf}]_{2}$ unlike in $\left[\mathrm{H}_{2} \mathrm{~L}^{1}\right][\mathrm{OTf}]_{2}$ as shown in Fig. 2. The ${ }^{1} \mathrm{H}$ and ${ }^{13} \mathrm{C}$ NMR (DMSO- $d_{6}$ ) spectra for $\left[\mathrm{H}_{2} \mathrm{~L}^{2}\right]$ $[\mathrm{OTf}]_{2}$ indicated the chemical equivalence in solution form of both pyridinium groups on NMR timescale. This lead to the appearance of only one signal for the both methyl groups at $3.81 \mathrm{ppm}$ in ${ }^{1} \mathrm{H}$ NMR and $44.4 \mathrm{ppm}$ in ${ }^{13} \mathrm{C}$ NMR spectra. Similarly, only one signal for $\mathrm{NH}$ appeared in ${ }^{1} \mathrm{H}$ NMR spectrum at $9.11 \mathrm{ppm}$. Though the individual atoms making up each of the pairs C2/C3 and C1/C4 (as well as their symmetry related pairs) within each pyridinium group were found unequal and we observed separate signals in each case. Such as, for C2/C2, C3/ $\mathrm{C} 3, \mathrm{C} 1 / \mathrm{C} 1$ and $\mathrm{C} 4 / \mathrm{C} 4$ in the ${ }^{13} \mathrm{C}$ NMR spectrum, separate singlet signals were observed at 144.35, 142.46, 110.37, and $106.31 \mathrm{ppm}$, respectively. This situation most likely result because of the conformational changes that equilibrate the positions of each of the pairs of atoms, C2/C3, C1/C4, C2/C3 and $\mathrm{C} 1 / \mathrm{C} 4$, were slow on the NMR timescale. Whereas the ${ }^{1} \mathrm{H}$ and ${ }^{13} \mathrm{C}$ NMR (DMSO- $d_{6}$ ) spectra of $\left[\mathrm{H}_{2} \mathrm{~L}^{1}\right][\mathrm{OTf}]_{2}$ showed the chemical equivalence of both pyridinium groups and the pairs of atoms $\mathrm{C} 1 / \mathrm{C} 4$ and $\mathrm{C} 2 / \mathrm{C} 3$ (and the corresponding pairs of atoms in the second pyridinium ring) in solution on NMR timescale. The interaction possibility of the $\mathrm{N} 1$ and $\mathrm{N} 1$ lone pairs in $\left[\mathrm{H}_{2} \mathrm{~L}^{1}\right]$
$[\mathrm{OTf}]_{2}$ with the head pyridine ring resulting in reduction of the N1/C5 and N1/C5 $\pi$-interactions is one possible explanation for this different behavior. Hence rotation about the N1-C5 bond became rapid on the NMR timescale.

Crystals suitable for single crystal XRD analysis were successfully grown for both precursors. $\left[\mathrm{P}^{3}{ }_{\mathrm{Et}}\right][\mathrm{I}]$ crystals were grown from its acetone solution through slow evaporation method. The ORTEP depiction of $\left[\mathrm{P}^{3}{ }_{\mathrm{Et}}\right][\mathrm{I}]$ is shown in Fig. 3 . The crystal structure of $\left[\mathrm{P}^{3}{ }_{\mathrm{Et}}\right][\mathrm{I}]$ confirms the successful ethylation of pyridine nitrogen. It also reveals that iodide acts as counter anion as well as replacement of $o$-chloro with iodo group. Crystals of $\left[\mathrm{P}^{2}{ }_{\mathrm{Me}}\right]\left[\mathrm{CF}_{3} \mathrm{SO}_{3}\right]$ were prepared through slow evaporation process from its methanol solution. The ORTEP depiction of $\left[\mathrm{P}^{2}{ }_{\mathrm{Me}}\right]\left[\mathrm{CF}_{3} \mathrm{SO}_{3}\right]$ is shown in Fig. 4 that shows successful methylation on nitrogen.

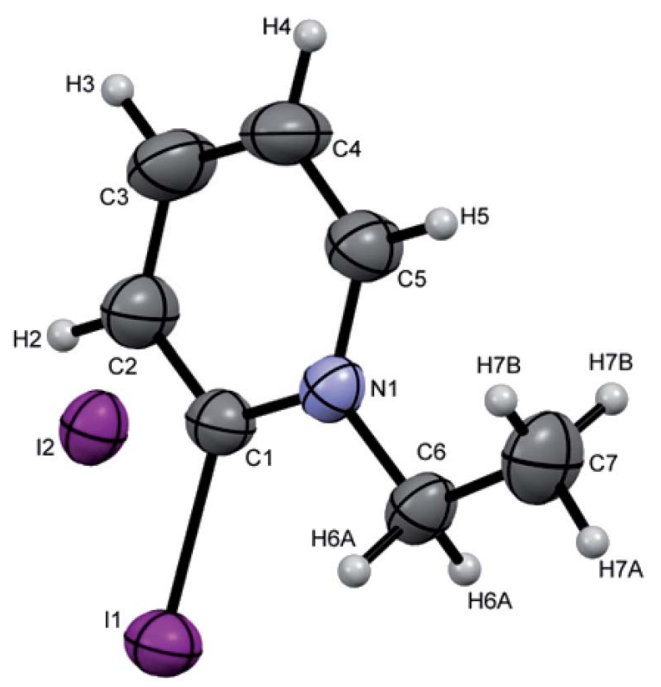

Fig. 3 ORTEP depiction of $\left[P_{E t}^{3}\right][I]$. 

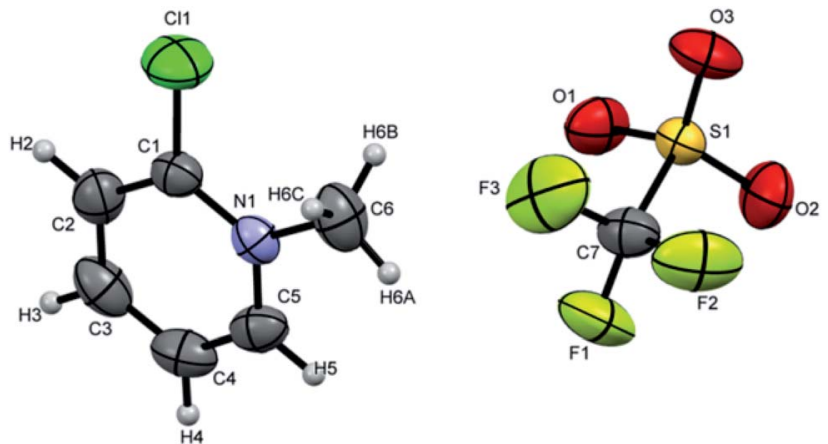

Fig. 4 ORTEP depiction of $\left[\mathrm{P}^{2} \mathrm{Me}\right]\left[\mathrm{CF}_{3} \mathrm{SO}_{3}\right]$

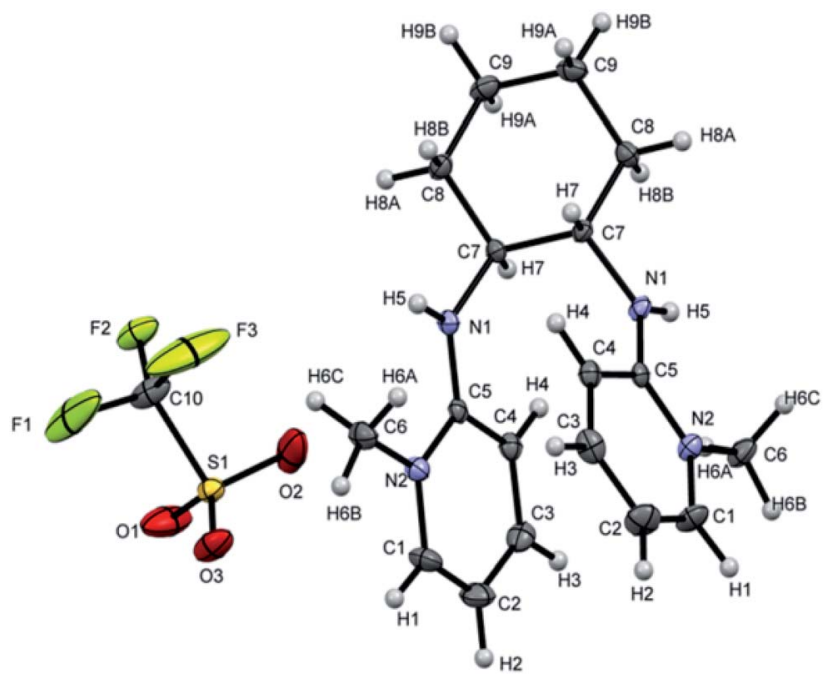

Fig. 5 ORTEP depiction of $\left[\mathrm{H}_{2} \mathrm{~L}^{3}\right][\mathrm{OTf}]_{2}$.

Attempts were made to grow the single crystals of all the ligands but $\left[\mathrm{H}_{2} \mathrm{~L}^{3}\right][\mathrm{OTf}]_{2}-\left[\mathrm{H}_{2} \mathrm{~L}^{5}\right][\mathrm{I}]_{2}$ were successfully grown and analyzed. $\left[\mathrm{H}_{2} \mathrm{~L}^{3}\right][\mathrm{OTf}]_{2}$ was crystallized out in $P b c n$ space group from dichloromethane and ether $(50: 50)$ solution. ORTEP diagram is shown in Fig. 4. Crystal structure analysis confirms the attachment of two pyridinium rings to the cyclohexyl diamine and triflate is acting as counter anion. Cyclohexyl group adopts chair conformation with two substitutions at consecutive axial and equatorial positions show transoid geometry. Due to steric repulsion, the two substituted arms of cyclohexyl group shows torsion C7N1C5N2 angle of $171.8^{\circ}$.(Fig. 5).

$\left[\mathrm{H}_{2} \mathrm{~L}^{4}\right][\mathrm{OTf}]_{2}$ was crystallized out in the space group $P 2_{1} / c$ in methanol and acetone solution. ORTEP depiction is shown in Fig. 6(A). Examination of crystal structure shows that there is torsion angle of $180.0^{\circ}$ (N1-C1-C2-N3). Fig. 6(B) presents the hydrogen bonding that exists with $\mathrm{NH}-\mathrm{O}$ distance of $2.92 \AA$ (N1 and $\mathrm{O} 2$ ). These distances are within the normal range of $\mathrm{NH}-\mathrm{O}$ bond lengths 2.81-3.04 $\left.\AA^{31} .{ }^{31} \mathrm{H}_{2} \mathrm{~L}^{5}\right][\mathrm{I}]_{2}$ was crystallized out in the space group $R \overline{3}$ in dichloromethane solvent. ORTEP depiction is shown in Fig. 7. Crystal structure cell coordinates reveal the

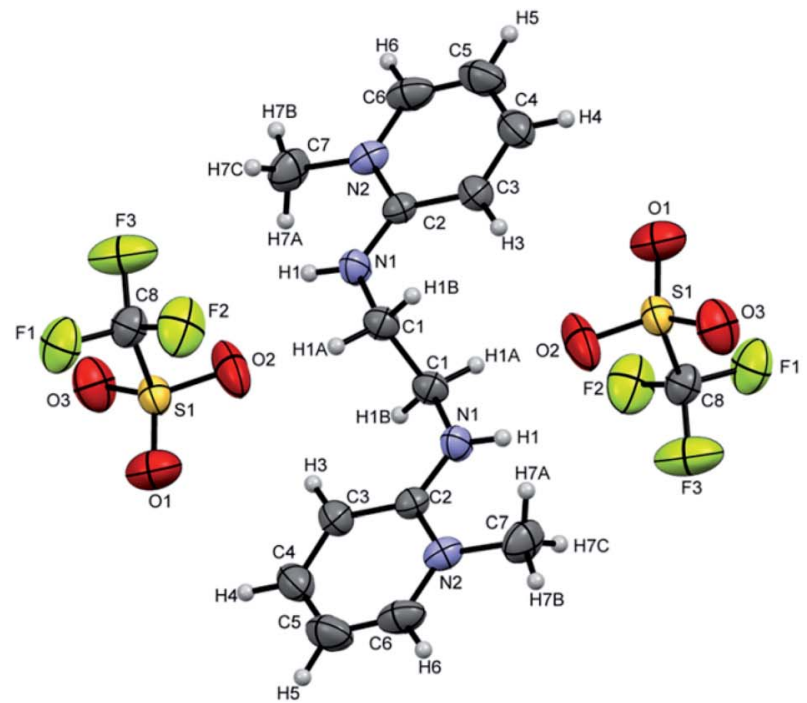

(A)

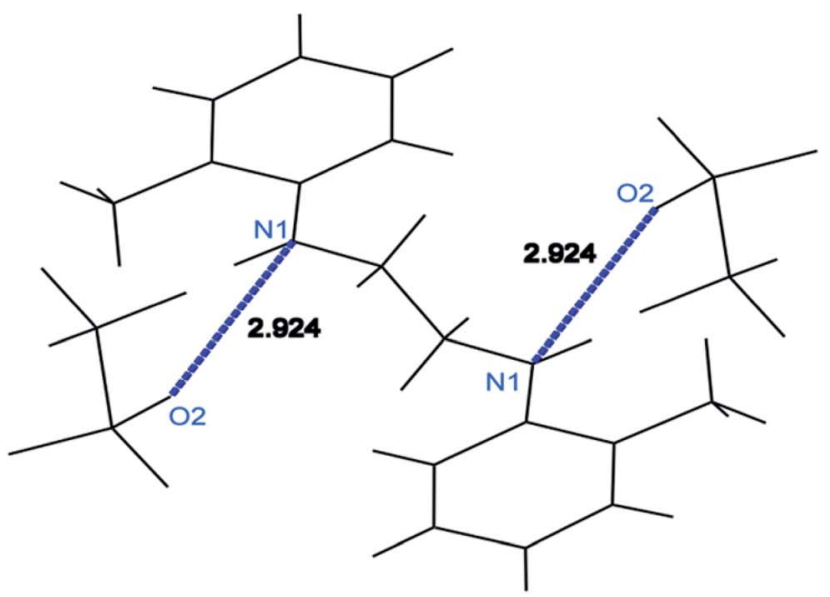

(B)

Fig. 6 (A) ORTEP depiction of $\left[\mathrm{H}_{2} \mathrm{~L}^{4}\right][\mathrm{OTf}]_{2}$, (B) wire frame work of $\left[\mathrm{H}_{2} \mathrm{~L}^{4}\right][\mathrm{OTf}]_{2}$ showing hydrogen bonding.

presence of monoclinic system. The X-ray crystal structure confirms that two pyridinium rings are attached to nitrogen atoms of bidentate ethylene diamine. The two pyridinium amine groups beside ethylene unit adopt transoid geometry due to N1C1C1N1 torsion angle of precise $180^{\circ}$ in both $\left[\mathrm{H}_{2} \mathrm{~L}^{4}\right][\mathrm{OTf}]_{2}$ and $\left[\mathrm{H}_{2} \mathrm{~L}^{5}\right][\mathrm{I}]_{2}$.

The wire frame work structures of $\left[\mathrm{H}_{2} \mathrm{~L}^{3}\right]^{+2}-\left[\mathrm{H}_{2} \mathrm{~L}^{5}\right]^{+2}$ are shown in Fig. 8(A). It reveals that the bond lengths of $\left[\mathrm{H}_{2} \mathrm{~L}^{3}\right]$ $[\mathrm{OTf}]_{2}-\left[\mathrm{H}_{2} \mathrm{~L}^{5}\right][\mathrm{I}]_{2}$ are in accordance with the resonance form $\mathrm{B}$ in Fig. 8(B). The bond length of $\mathrm{C} 5-\mathrm{N} 1$ is $1.347 \AA$ in $\left[\mathrm{H}_{2} \mathrm{~L}^{3}\right][\mathrm{OTf}]_{2}$. Similarly $\left[\mathrm{H}_{2} \mathrm{~L}^{4}\right][\mathrm{OTf}]_{2}$ and $\left[\mathrm{H}_{2} \mathrm{~L}^{5}\right][\mathrm{I}]_{2} \mathrm{C} 2-\mathrm{N} 1$ bond distances are $1.338 \AA$ and $1.331 \AA$ respectively that correspond to exocyclic carbon double bond nitrogen.

\subsection{Computational analysis of molecular structures}

Computational studies were carried out on all the compounds using Gaussian 09 software to gain a greater insight into the 


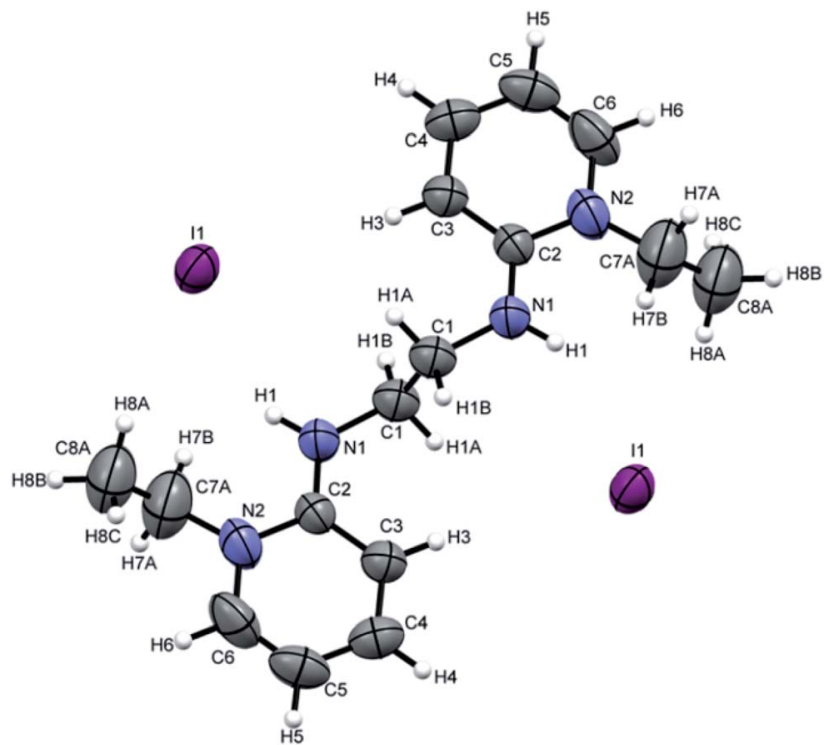

Fig. 7 ORTEP depiction of $\left[\mathrm{H}_{2} \mathrm{~L}^{5}\right][]_{2}$. structural and electronic properties. The most significant edge to semi-empirical calculations is the prominent increase in computational accuracy without further increase in computing time. The geometry optimization of the structures was performed using AM1 semi-empirical method and an energy calculation was carried out for each optimized structure to find the energy minimum, (in the presence and absence of ligands). The energy of the frontier molecular orbitals (HOMO-LUMO) was also calculated (and confirmed to earlier results by Gaussian) by MOE 2016 software ${ }^{32}$ using semi-empirical method with a Hamiltonian force field, MMFF94x and 0.0001 Gradient. All the computed data available in this study shows highly convergent values obtained from energy minimization of compounds using Gaussian and MOE.

A number of structural parameters have been obtained from semi-empirical studies on conformers with minimum energy. The energy of the frontier molecular orbitals is also instrumental in obtaining the values of chemical hardness $(\eta)$, chemical potential $(\chi)$ and electrophilicity index $(\omega)$ using the
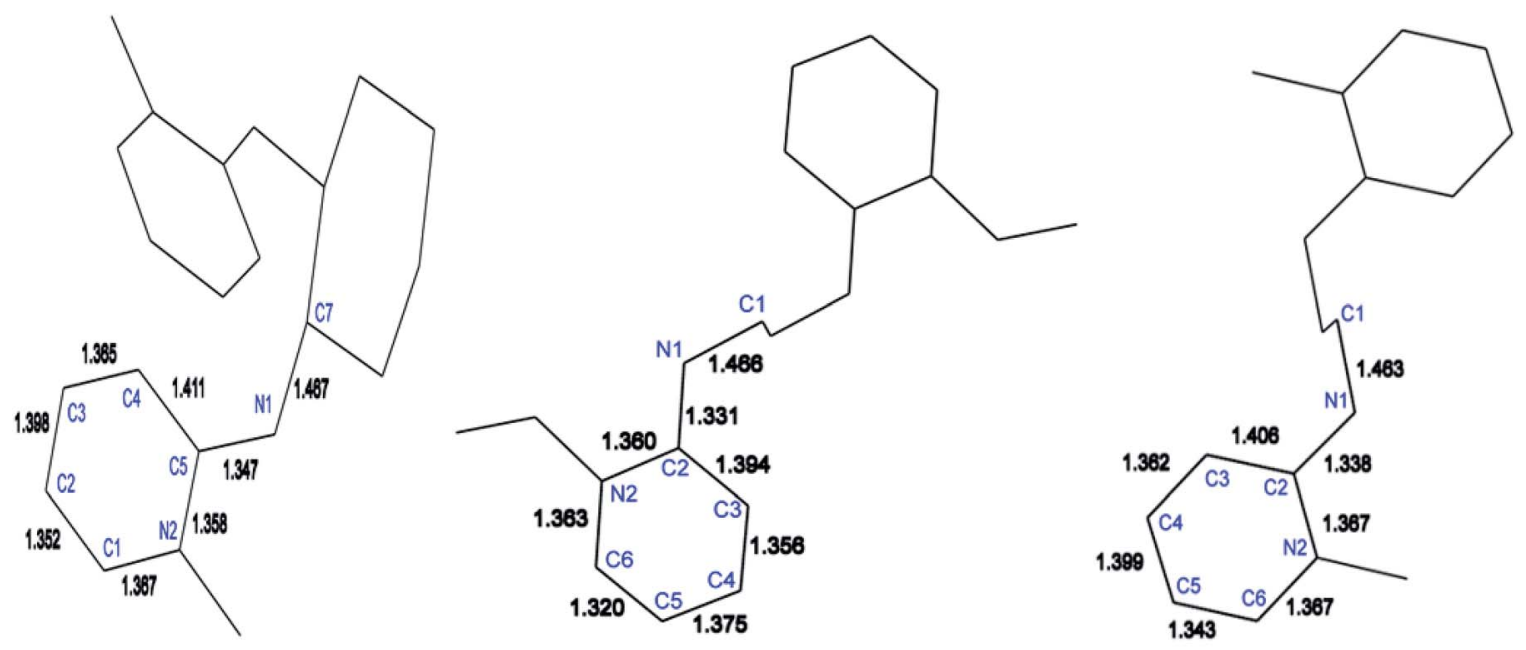

(A)

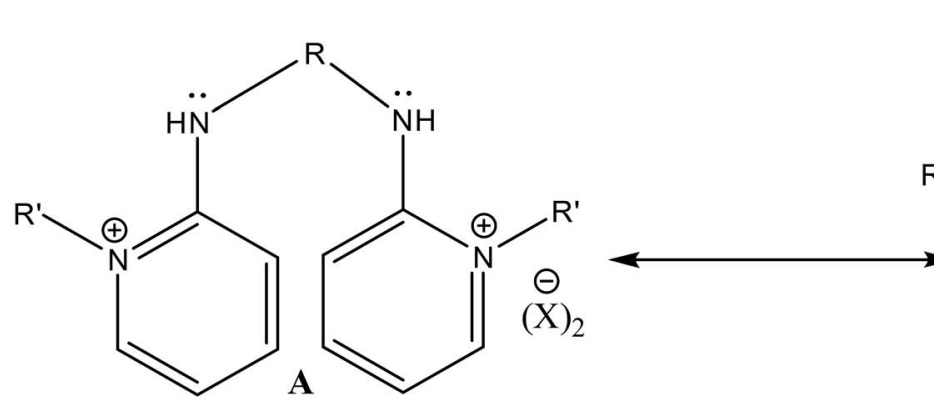<smiles>[R]N=c1ccccn1[N+]([R])=[NH+]</smiles>

Here R=Et, Cyclohexyl

$\mathrm{R}^{\prime}=\mathrm{Me}, \mathrm{Et}$

$\mathrm{X}=\mathrm{TfO}, \mathrm{I}$

(B)

Fig. 8 (A) Wire framework of $\left[\mathrm{H}_{2} \mathrm{~L}^{3}\right]^{2+}-\left[\mathrm{H}_{2} \mathrm{~L}^{5}\right]^{2+}$ showing important bond distances, (B) resonance forms of $\left[\mathrm{H}_{2} \mathrm{~L}^{3}\right][\mathrm{OTf}]_{2}-\left[\mathrm{H}_{2} \mathrm{~L}^{5}\right][\mathrm{ll}]_{2}$. 
Table 1 Ionization energy, electron affinity and band gap values of $\left[\mathrm{P}^{3} \mathrm{Et}\right][\mathrm{I}]-\left[\mathrm{H}_{2} \mathrm{~L}^{5}\right][\mathrm{I}]_{2}$

\begin{tabular}{|c|c|c|c|c|}
\hline Ligands & Values $(\mathrm{eV})$ & $\begin{array}{l}\text { Ionization energies } \\
\text { (eV per molecule) }\end{array}$ & $\begin{array}{l}\text { Electron affinity } \\
\text { (eV per molecule) }\end{array}$ & $\begin{array}{l}\text { Band gap (eV } \\
\text { per molecule) }\end{array}$ \\
\hline$\left[\mathrm{P}_{\mathrm{Et}}^{3}\right][\mathrm{I}]$ & HOMO $=-8.15$, LUMO $=-0.47$ & -8.15 & -0.47 & -7.67 \\
\hline$\left[\mathrm{H}_{2} \mathrm{~L}^{1}\right][\mathrm{OTf}]_{2}$ & HOMO $=-14.69$, LUMO $=-6.77$ & -14.69 & -6.77 & -8.22 \\
\hline$\left[\mathrm{H}_{2} \mathrm{~L}^{2}\right][\mathrm{OTf}]_{2}$ & HOMO $=-14.50$, LUMO $=-6.12$ & -14.50 & -6.12 & -8.38 \\
\hline$\left[\mathrm{H}_{2} \mathrm{~L}^{3}\right][\mathrm{OTf}]_{2}$ & HOMO $=-9.49$, LUMO $=-2.55$ & -9.49 & -2.55 & -6.94 \\
\hline
\end{tabular}

Table 2 Chemical hardness $(\eta)$, chemical potential $(\chi)$ and electrophilicity index $(\omega)$ of $\left[P^{3}{ }_{E t}\right][l]-\left[H_{2} L^{5}\right][I]_{2}$

\begin{tabular}{llll}
\hline Ligands & $\begin{array}{l}\text { Chemical } \\
\text { hardness }(\eta)\end{array}$ & $\begin{array}{l}\text { Chemical } \\
\text { potential }(\chi)\end{array}$ & $\begin{array}{l}\text { Electrophilicity } \\
\text { index }(\omega)\end{array}$ \\
\hline$\left[\mathrm{P}^{3}\right][\mathrm{I}]$ & -4.31 & 4.31 & -2.15 \\
{$\left[\mathrm{P}^{2}{ }_{\mathrm{Me}}\right]$} & -5.83 & 5.83 & -2.91 \\
{$\left[\mathrm{CF}_{3} \mathrm{SO}_{3}\right]$} & & & \\
{$\left[\mathrm{H}_{2} \mathrm{~L}^{1}\right][\mathrm{OTf}]_{2}$} & -10.73 & 10.73 & -5.36 \\
{$\left[\mathrm{H}_{2} \mathrm{~L}^{2}\right][\mathrm{OTf}]_{2}$} & -10.31 & 10.31 & -5.15 \\
{$\left[\mathrm{H}_{2} \mathrm{~L}^{3}\right][\mathrm{OTf}]_{2}$} & -6.02 & 6.02 & -3.01 \\
{$\left[\mathrm{H}_{2} \mathrm{~L}^{4}\right][\mathrm{OTf}]_{2}$} & -5.74 & 5.74 & -2.87 \\
{$\left[\mathrm{H}_{2} \mathrm{~L}^{5}\right][\mathrm{I}]_{2}$} & -10.78 & 10.78 & -5.39
\end{tabular}

eqn (1)-(3); ${ }^{33,34}$ where $I$ and $A$ are the ionization potential and electron affinity of a molecule, shown in Tables 1 and 2 .

$$
\begin{gathered}
\eta=(I-A) / 2 \\
\chi=-(I+A) / 2
\end{gathered}
$$

$$
\omega=\chi^{2} / 2 \eta
$$

The reactivity of a compound can also be gauged from the HOMO and LUMO orbitals energy difference $\left(\Delta E_{\mathrm{H}-\mathrm{L}}\right)$; a larger band gap indicates lower reactivity and higher chemical hardness. ${ }^{35,36}$ The greater is the energy of HOMO, greater would be ionization potential and thus more is the ability of a molecule to donate an electron pair. While LUMO has the ability to accept electron density via back bonding from transition metal that is associated with electron affinity of molecule..$^{37,38}$ The pictorial representations of all the frontier molecular orbitals (HOMOLUMO) were acquired. HOMO-LUMO of $\left[\mathrm{P}_{\mathrm{Et}}^{3}\right][\mathrm{I}]$ and $\left[\mathrm{H}_{2} \mathrm{~L}^{1}\right]$ [OTf $]_{2}$ are shown in Fig. 9 and 10. The important bond lengths of optimized structures and XRD structures of compounds $\left[\mathrm{H}_{2} \mathrm{~L}^{3}\right][\mathrm{OTf}]_{2}-\left[\mathrm{H}_{2} \mathrm{~L}^{5}\right][\mathrm{I}]_{2}$ are compared in Tables 3-5. It shows good agreement between the computed and experimental values for all the compounds. Slight divergences in some bond lengths can be attributed to the choice of computational method, and the basis set used..$^{35-39}$

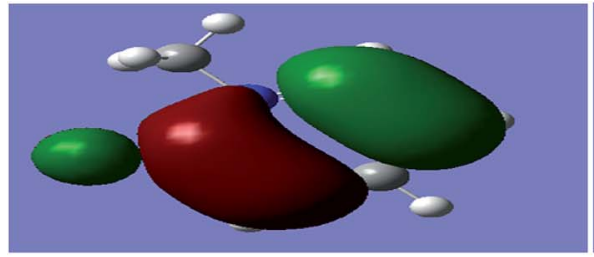

HOMO $(-9.39 \mathrm{eV})$

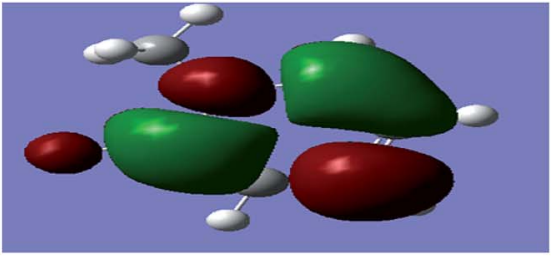

LUMO (-2.27eV)

Fig. 9 Electron density distribution of $\mathrm{HOMO}$ and LUMO of $\left[\mathrm{P}^{3} \mathrm{Et}\right][\mathrm{I}]$.

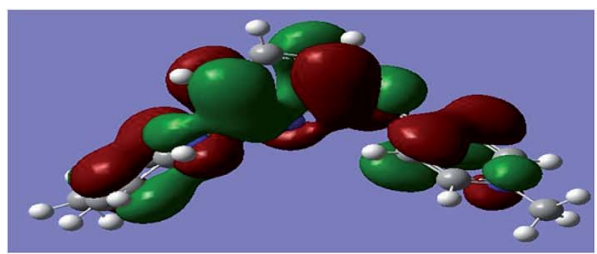

HOMO $(-14.69 \mathrm{eV})$

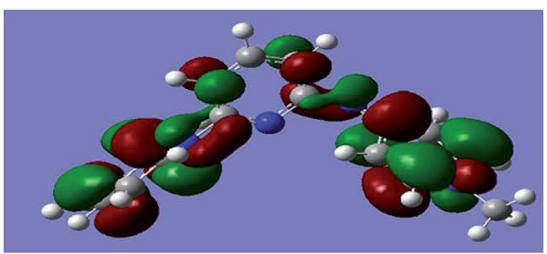

LUMO (-6.77eV)

Fig. 10 Electron density distribution of $\mathrm{HOMO}$ and LUMO of $\left[\mathrm{H}_{2} \mathrm{~L}^{1}\right][O T f]_{2}$. 
Table 3 Experimental and theoretical bond lengths $[\AA \AA]$ of $\left[\mathrm{H}_{2} \mathrm{~L}^{3}\right][\mathrm{OTf}]_{2}$

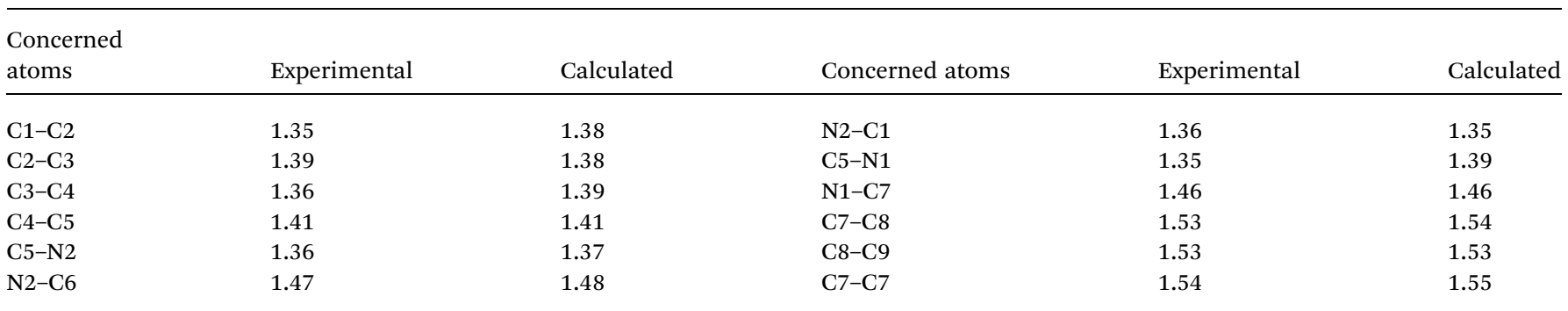

Table 4 Experimental and theoretical bond lengths $[\AA ̊]$ of $\left[\mathrm{H}_{2} \mathrm{~L}^{4}\right][\mathrm{OTf}]_{2}$

\begin{tabular}{lllllr}
\hline Atom no & Experimental & Calculated & Atom no & Experimental \\
\hline C1-N1 & 1.46 & 1.48 & C5-C6 & 1.34 & 1.36 \\
N1-C2 & 1.34 & 1.34 & C6-N2 & N2-C7 & 1.46 \\
C2-C3 & 1.40 & 1.41 & N2-C2 & 1.36 & 1.35 \\
C3-C4 & 1.36 & 1.39 & C1-C1 & 1.51 & 1.38 \\
C4-C5 & 1.39 & 1.38 & & 1.52 \\
\hline
\end{tabular}

Table 5 Experimental and theoretical bond lengths $[\AA]$ of $\left[\mathrm{H}_{2} \mathrm{~L}^{5}\right][]_{2}$

\begin{tabular}{|c|c|c|c|c|c|}
\hline C1-N1 & 1.46 & 1.45 & C5-C6 & 1.32 & 1.38 \\
\hline $\mathrm{C} 2-\mathrm{C} 3$ & 1.39 & 1.41 & $\mathrm{~N} 2-\mathrm{C} 7$ & 1.49 & 1.49 \\
\hline C3-C4 & 1.36 & 1.39 & $\mathrm{C} 7-\mathrm{C} 8$ & 1.46 & 1.52 \\
\hline C4-C5 & 1.37 & 1.38 & C5-C6 & 1.32 & 1.38 \\
\hline
\end{tabular}

\subsection{Evaluation of Mizoroki-Heck cross-coupling reaction}

The estimation of potential efficiency of $\left[\mathrm{H}_{2} \mathrm{~L}^{1}\right][\mathrm{OTf}]_{2}-\left[\mathrm{H}_{2} \mathrm{~L}^{5}\right][\mathrm{I}]_{2}$ as a co-catalysts toward Heck coupling reaction were evaluated in the presence of palladium acetates catalyst. The results obtained are tabulated in Table $6 .\left[\mathrm{H}_{2} \mathrm{~L}^{1}\right][\mathrm{OTf}]_{2}$ was used for the optimization of various parameters such as amount of catalyst loading (Table 6, entry 1-5), solvent system (Table 6, entry 5-9), base (Table 6, entry 10-15), temperature (Table 6, entry 15-19) and molar ratio of palladium acetate to ligand (Table 6 , entry $19-20,21,22)$, with pure $\mathrm{Pd}(\mathrm{OAc})_{2}$ catalyst and without any ligand reaction time 4 hours resulted in lowest $6 \%$ yield (Table 6 , entry 20). Initially, bromobenzene with styrene reaction was selected for optimization of reaction conditions. A reaction with only palladium acetate or ligand yield trace amount of product (Table 6 , entry 1 or 20 ). The optimum reaction conditions were obtained for (entry 19, Table 6); $0.01 \mathrm{~mol} \%$ palladium acetate, DMF solvent, NaOAc $1.1 \mathrm{mmol}, 130{ }^{\circ} \mathrm{C}$ and $1: 1$ palladium acetate to $\left[\mathrm{H}_{2} \mathrm{~L}^{1}\right][\mathrm{OTf}]_{2}$.

All the other synthesized ligands, $\left[\mathrm{H}_{2} \mathrm{~L}^{2}\right][\mathrm{OTf}]_{2}-\left[\mathrm{H}_{2} \mathrm{~L}^{5}\right][\mathrm{I}]_{2}$, were compared with $\left[\mathrm{H}_{2} \mathrm{~L}^{1}\right][\mathrm{OTf}]_{2}$ and the results are shown (Table 7 ). $\left[\mathrm{H}_{2} \mathrm{~L}^{1}\right][\mathrm{OTf}]_{2}$ presented maximum coupled product comparatively. The reason can be associated with the extensive delocalization of electrons in the in situ generated $\mathrm{L}^{1}$ (Fig. 11) that binds with palladium acetate. This conjugation in ligand can make amido nitrogen electron rich that in turn increases the electronic density on palladium catalyst that eventually speeds up the rate of oxidative addition of bromobenzene, thus activating the catalyst towards coupling reaction.

Alkyl substituted ligands, $\left[\mathrm{H}_{2} \mathrm{~L}^{2}\right][\mathrm{OTf}]_{2}-\left[\mathrm{H}_{2} \mathrm{~L}^{5}\right][\mathrm{I}]_{2}$, were found less active comparatively. Nevertheless, they showed coupled product in the range of 77 to $83 \%$ owing to the inductive effect of ethyl and hexyl groups. The minor variations in product yield can be related to the steric of $N$-alkylated group of varying degree around the donor amido nitrogen. This catalytic activity order of co-catalysts can also be related with their $E_{\text {HOMO }}$ values i.e., greater is the energy of HOMO, greater would be the electron donation from ligand to $\operatorname{Pd}(\mathrm{II})$ thus more would be the stability of in situ generated active catalyst.

Substrates with a different range of electron withdrawing to electron donating substituent were coupled under optimum conditions to test the substrate scope of best catalyst system $\left(\left[\mathrm{H}_{2} \mathrm{~L}^{1}\right][\mathrm{OTf}]_{2} /\right.$ Palladium acetate $)$. As expected, more activated aryl iodides couple more effectively than aryl bromides and aryl chloride (Table 8 , entry 1-8). The high reactivity of aryl iodides are due to small dissociation energy of C-I bond and ease of activation towards $\operatorname{Pd}(0)$ catalyst in oxidative addition 


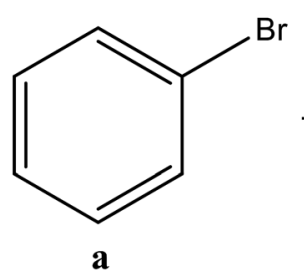

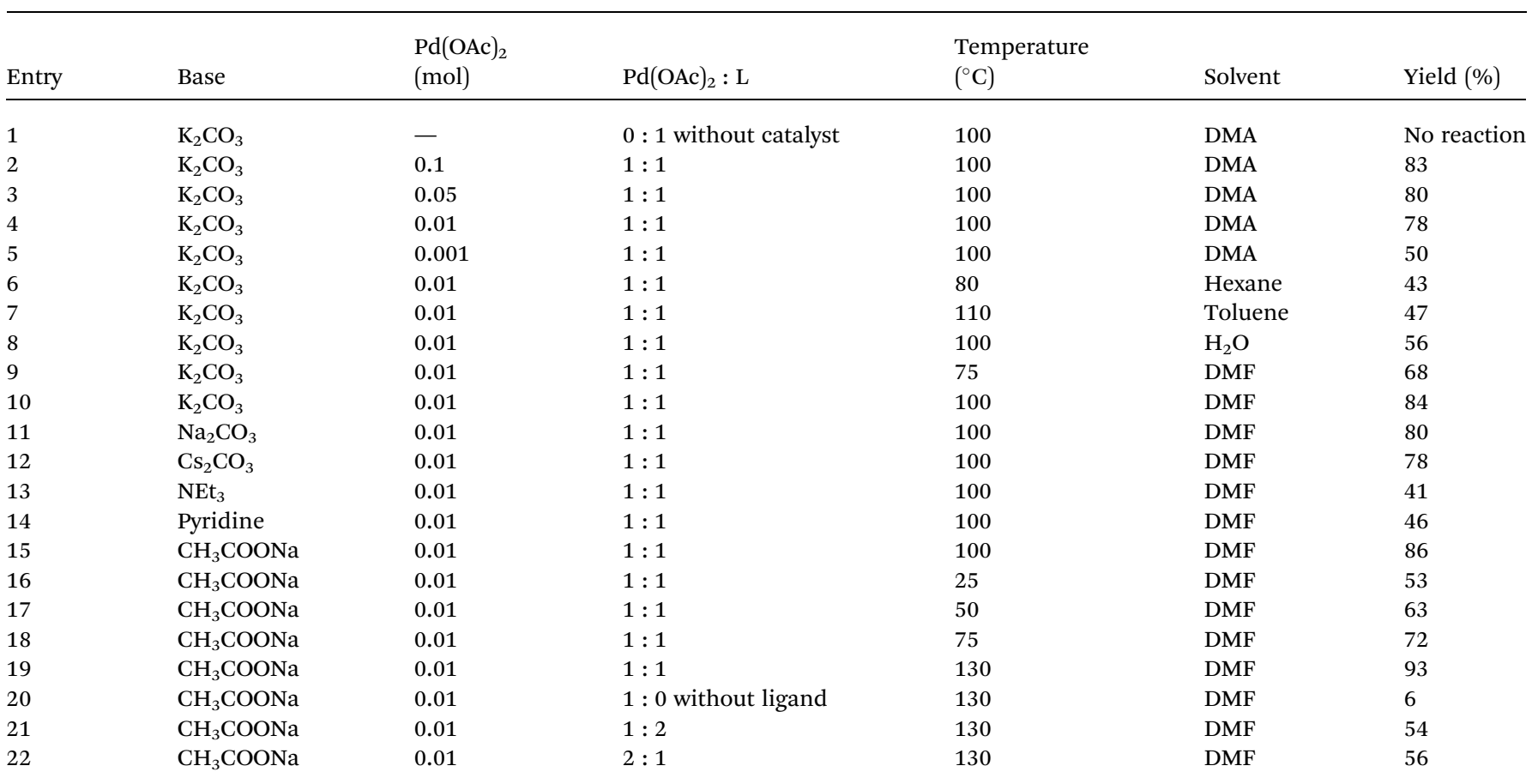

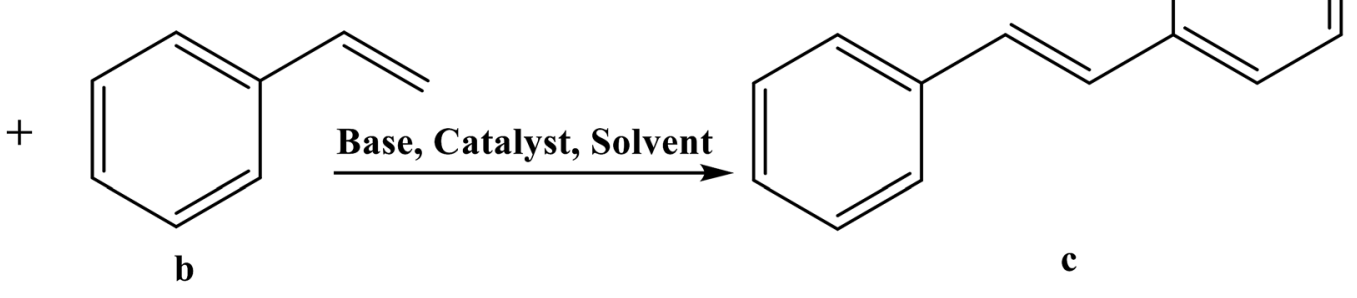

c

${ }^{a}$ Conditions: 3 h except entry 20, styrene (1.4 eq.) versus halobenzene. Isolated yields were based on aryl halide.

Table 7 Comparison of $\left[\mathrm{H}_{2} \mathrm{~L}^{1}\right][\mathrm{OTf}]_{2}-\left[\mathrm{H}_{2} \mathrm{~L}^{5}\right]\left[\mathrm{I}_{2}\right.$ for Mizoroki-Heck cross coupling reactions ${ }^{a}$

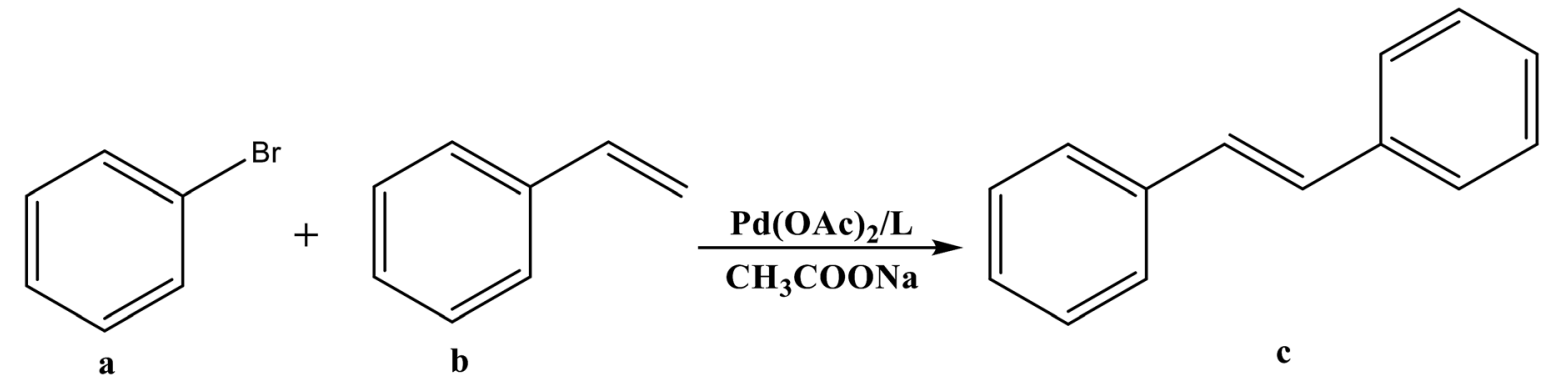

\begin{tabular}{lll}
\hline Entry & Ligands & $\%$ Yield \\
\hline 1 & {$\left[\mathrm{H}_{2} \mathrm{~L}^{1}\right][\mathrm{TfO}]_{2}$} & 93 \\
2 & {$\left[\mathrm{H}_{2} \mathrm{~L}^{2}\right][\mathrm{TfO}]_{2}$} & 83 \\
3 & {$\left[\mathrm{H}_{2} \mathrm{~L}^{3}\right][\mathrm{TfO}]_{2}$} & 81 \\
4 & {$\left[\mathrm{H}_{2} \mathrm{~L}^{4}\right][\mathrm{TfO}]_{2}$} & 79 \\
5 & {$\left[\mathrm{H}_{2} \mathrm{~L}^{5}\right][\mathrm{I}]_{2}$} & 77
\end{tabular}

${ }^{a}$ Conditions: $3 \mathrm{~h}, 130{ }^{\circ} \mathrm{C}$, styrene (1.4 eq.) versus halobenzene, $\mathrm{Pd}(\mathrm{OAc})_{2}: \mathrm{L}=1: 1$, DMF $(2 \mathrm{~mL})$, ligand loading $(0.01 \mathrm{~mol})$, $\mathrm{Pd}(\mathrm{OAc})_{2}$ loading $(0.01$ $\mathrm{mol}$ ) and NaOAc (4.3 mmol, 3.1 eq.). Isolated yield based on aryl halide. 
<smiles>Cn1ccc(=Nc2cccc(N=c3ccn(C)cc3)n2)cc1</smiles>

Fig. 11 Proposed structure of $L^{1}$.

step. $^{40}$ Generally coupling of aryl chlorides demand high catalyst loading with low yield of coupled product. ${ }^{41}$

Likewise, those aryl halides with electron donating substituents like methoxy, methyl or naphthyl and electron neutral group such as $-\mathrm{H}$ showed less reactivity than aryl halide containing electron withdrawing substituents such as nitro, aldo and keto groups (Table 8, entry 1-13). The more electron deficient quaternary carbon of aryl halide better would be the rate of oxidative addition reaction. Similar trend was shown by ethyl acrylate for the above mentioned aryl halides activated to different degrees. However the yield of all coupled products with ethyl acrylate was comparatively more than styrene (Table 8 , entry 14-18). The reason can be attributed to the greater polarization of the alkene with more electron-withdrawing adjacent carbonyl group in ethyl acrylate. This polarization enhances the insertion of ethyl acrylate into aryl-palladium bond during catalytic cycle. Moreover, as explained earlier, out of 3.1 eq. sodium acetate, 1.1 eq. of sodium acetate was used for catalytic reaction however remaining 2 eq. of sodium acetate was used to in situ deprotonate the ligand leading to the formation of an effective complex with ligand.

Efforts to synthesize pure palladium complexes with all the ligands, $\left[\mathrm{H}_{2} \mathrm{~L}^{1}\right][\mathrm{OTf}]_{2}-\left[\mathrm{H}_{2} \mathrm{~L}^{5}\right][\mathrm{I}]_{2}$ were proved to be futile owing to strong trans influence by in situ generated deprotonated ligands. The resulted mixtures were attempted to be purified by various analytical techniques but was proved in vain. To full fill the urge of identifying the actual nature of catalyst, standard mercury test was performed. 150 to 300 equivalent of $\mathrm{Hg}(0)$

Table 8 Synthesis of aryl halides catalyzed by $\mathrm{Pd}(\mathrm{OAc})_{2} / \mathrm{L}$ through Mizoroki-Heck cross-coupling reaction ${ }^{a}$

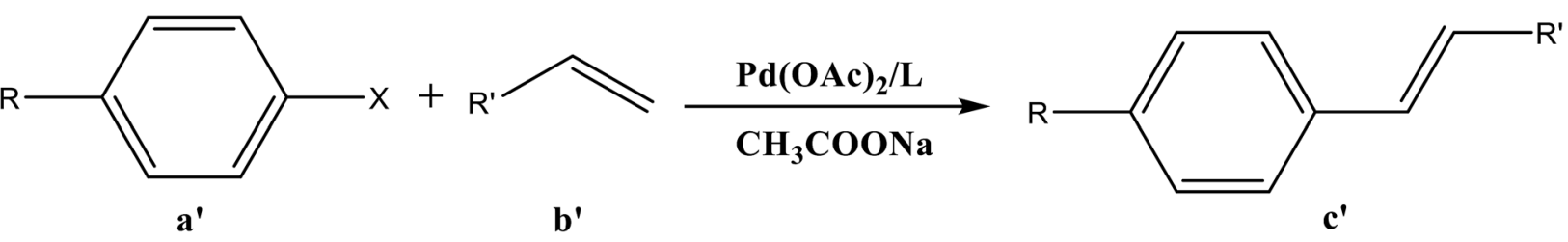

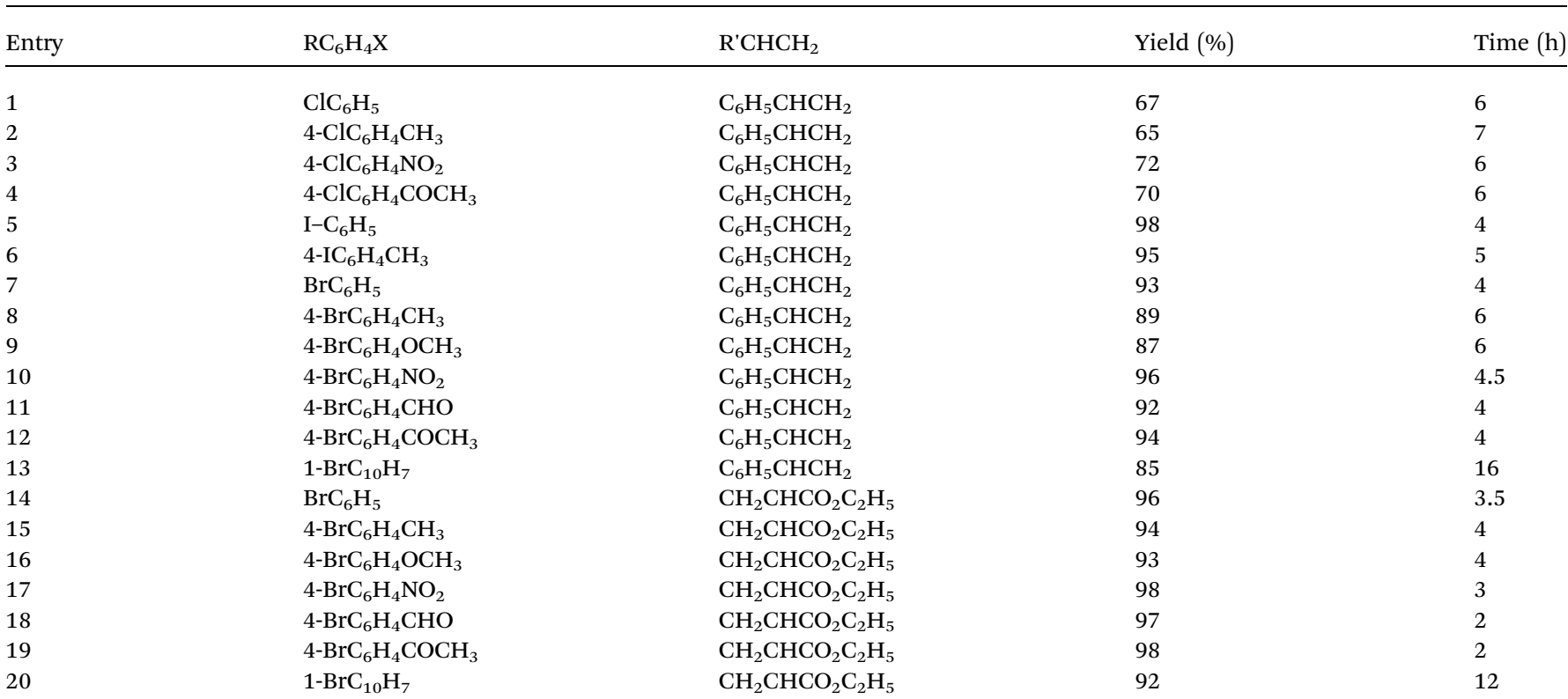

${ }^{a}$ Conditions: $130{ }^{\circ} \mathrm{C}$, styrene (1.4 eq.) versus halobenzene, $\mathrm{Pd}(\mathrm{OAc})_{2}: \mathrm{L}=1: 1$, NaOAc (4.3 mmol, 3.1 eq.), DMF ( $\left.2 \mathrm{~mL}\right)$, ligand loading 0.01 , $\mathrm{Pd}(\mathrm{OAc})_{2}$ loading $(0.01 \mathrm{~mol} \%)$. Isolated yield based on aryl halide. 


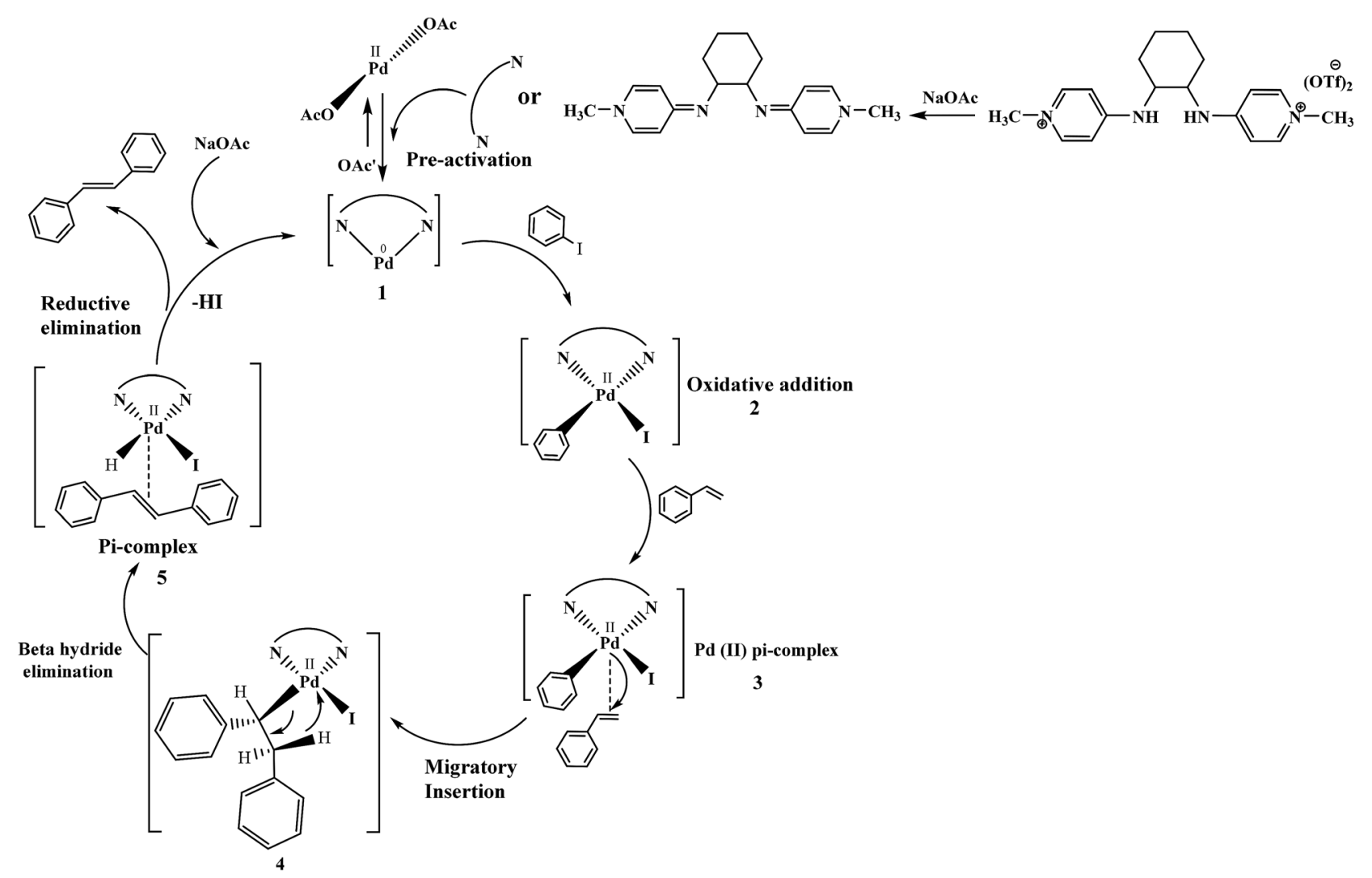

Fig. 12 The catalytic cycle showing the role of reagents, ligands and etc., under the best reaction conditions.

compared to catalytic system was added in the catalytic reactor during coupling reaction. The yield of coupled product was not affected in this test reaction. This result clearly confirmed the in situ generation of homogeneous palladium catalysts and heterogeneous $\operatorname{Pd}(0)$ catalysts were not obtained by any opponent way. ${ }^{42,43}$

The plausible catalytic cycle of one of the reactions between iodobenzene and styrene under the best reaction conditions (mentioned in Table 8) shown in Fig. 12 involved preactivation of catalyst followed by oxidative addition of palladium in benzene to iodide bond of iodobenzene, $\operatorname{Pd}(\mathrm{II}) \pi$ complex formation, migratory insertion of styrene in palladium and carbon bond, relief of torsional strain with the elimination of beta hydride, another $\pi$-complex formation with stilbene and generation of $\operatorname{Pd}(0)$ catalyst with reductive elimination. Sodium acetate plays a vital role in regeneration of catalyst. ${ }^{44}$

Herein, we performed the critical comparison (mentioned in Table 9) of the catalytic activity (entry 1 to 5$)^{45 a-e}$ of this work in entry 6 related to Heck coupling of chlorobenzene and styrene with literature showed that this catalyst is potentially the trademark for the coupling of chlorobenzene with styrene. It gave $67 \%$ yield in 6 hours at $130{ }^{\circ} \mathrm{C}$ with $1 \mathrm{~mol} \%$. The problem with catalysts in entries 1 and 2 catalysts is utilization of too much time for catalytic conversion of chlorobenzene to coupled product. The catalyst in entry 3 yields $70 \%$ coupled product in just 85 minutes at $120{ }^{\circ} \mathrm{C}$ but with much high catalyst amount i.e. $10 \mathrm{~mol} \%$. The best one seems to be in entry 4 ; utilizes less catalyst at the cost of $20{ }^{\circ} \mathrm{C}$ more temperature comparatively. The catalyst in entry 5 is useless for chlorobenzenes. Whereas with respect to catalyst shown in entry 4, our catalysts showed more substrate scope for chlorobenzenes.

We observed a probable limitation of our new catalytic system entry 12 as it was not found to be the best for the Heck coupling of iodobenzenes with styrene. The published literature $45 c, h$ (entry 10 and 11) proved it inferior to them with respect to catalyst loading but it still looks reasonable when compared to entries 7-9 (ref. 45a, $f, g$ ) of the above table.

The comparison of our result with literature with regard to the Heck coupling of bromobenzene with alkyl acrylate (entries 13-15) ${ }^{45 f, i, j}$ suggested that the catalyst system generated in this work (entry 19) proved to be an excellent attempt specially with respect to very less time utilization (3.5 hours). Likhar et al. ${ }^{45 f}$ got $92 \%$ of coupled product with $0.01 \mathrm{~mol} \%$ but in $20 \mathrm{~h}$ and at $145^{\circ} \mathrm{C}$. In 2017, Abdol R. Hajipour ${ }^{45 i}$ synthesized highly active catalyst and got $95 \%$ yield at only $50{ }^{\circ} \mathrm{C}$ but using more time than our catalytic system i.e. 5 hours. Wang et al. ${ }^{45 j}$ used $0.005 \mathrm{~mol} \%$ of catalyst but with only $4 \%$ yield. The other remarkable feature of our catalyst (entry 16) was the use of $400 \mathrm{mmol}$ of halobenzene transformed into $96 \%$ of coupled product compared to literature (1 mmol) (Table 9). 
Table 9 Comparison of developed catalytic system (entries 6, 14, 16) with the literature reported systems (entries 1-5, 7-11, 13-15) showing different ligands and conditions ${ }^{a}$

\begin{tabular}{|c|c|c|c|c|c|c|c|c|}
\hline Entry & Reactions & $\begin{array}{l}\text { Halo-benzene } \\
(\mathrm{mmol})\end{array}$ & Ligands (L), $\mathrm{Pd}(\mathrm{OAc})_{2}$ mol\% & $\begin{array}{l}\text { Solvent }(\mathrm{ml}) \text {, } \\
\text { base }\end{array}$ & Time (h) & $T\left({ }^{\circ} \mathrm{C}\right)$ & $Y(\%)$ & Ref. \\
\hline
\end{tabular}

$1 \quad \mathrm{C}_{6} \mathrm{H}_{5} \mathrm{Cl}+$ styrene $\quad 1$

$\mathrm{C}_{6} \mathrm{H}_{5} \mathrm{Cl}+$ styrene

2

$\mathrm{C}_{6} \mathrm{H}_{5} \mathrm{Cl}+$ styrene

0.5

$\mathrm{C}_{6} \mathrm{H}_{5} \mathrm{Cl}+$ styrene

1

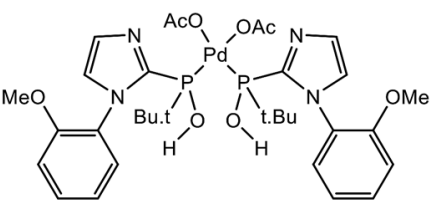

2

$\mathrm{Pd}(\mathrm{OAc})_{2}:$ Dave-Phos $(2: 6) 2$

3

1.5

5

$\mathrm{C}_{6} \mathrm{H}_{5} \mathrm{Cl}+$ styrene

1

7

$\mathrm{C}_{6} \mathrm{H}_{5} \mathrm{I}+$ styrene

1

8

\subsection{5}

6

$\mathrm{C}_{6} \mathrm{H}_{5} \mathrm{Cl}+$ styrene $\quad 400$

$\mathrm{Pd}(\mathrm{OAc})_{2}:\left[\mathrm{H}_{2} \mathrm{~L}^{1}\right][\mathrm{TfO}]_{2}(1: 1)$

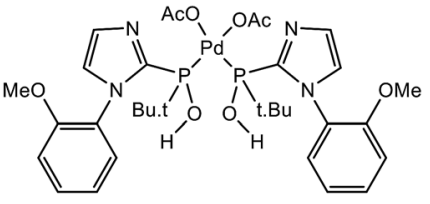

2

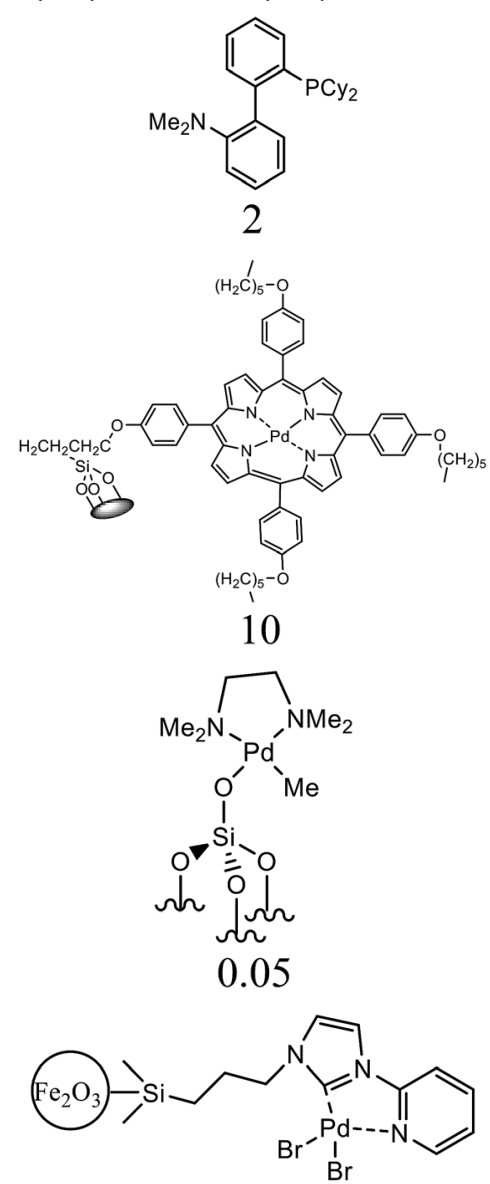

$\mathrm{C}_{6} \mathrm{H}_{5} \mathrm{Cl}+$ styrene

1,4- dioxane, 24

TBAE

DMF, $\mathrm{K}_{2} \mathrm{CO}_{3}$

12

$60 \quad 62$

$45 a$

$\mathrm{K}_{2} \mathrm{CO}_{3}, \mathrm{DMF} \quad 85 \mathrm{~min} \quad 120 \quad 70 \quad 45 \mathrm{c}$

$\mathrm{NMP}, \mathrm{Ca}(\mathrm{OH})_{2} \quad 6$

150

62

$45 d$

DMF, NaOAc

6

130

67

This work

DMF, $\mathrm{K}_{2} \mathrm{CO}_{3} \quad 12$

60

98

$45 a$<smiles></smiles>

DMF, $\mathrm{Na}_{2} \mathrm{CO}_{3} \quad 20 \quad 145 \quad 95 \quad 45 f$ 
Table 9 (Contd.)

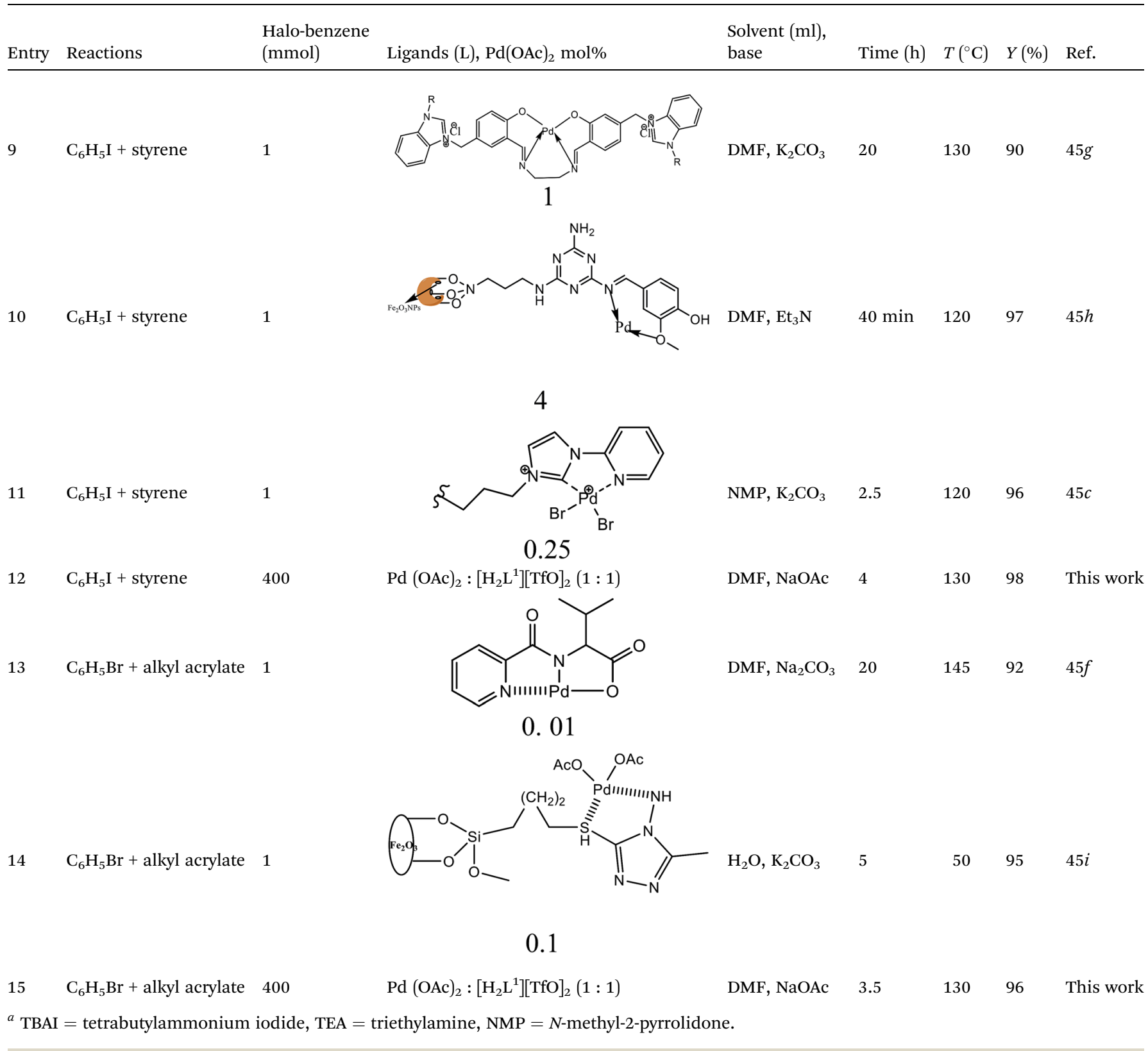

\section{Conclusion}

In conclusion, five new ligands, $\left[\mathrm{H}_{2} \mathrm{~L}^{1}\right][\mathrm{OTf}]_{2}-\left[\mathrm{H}_{2} \mathrm{~L}^{5}\right][\mathrm{I}]_{2}$, were synthesized from two new precursors, $\left[\mathrm{P}^{3} \mathrm{Et}\right][\mathrm{I}]$ and $\left[\mathrm{P}^{2}{ }_{\mathrm{Me}}\right]$ $\left[\mathrm{CF}_{3} \mathrm{SO}_{3}\right]$. These ligands were successfully synthesized by the melt reaction between precursor and corresponding diamine. All the synthesized compounds were successfully characterized by various analytical techniques such as ${ }^{1} \mathrm{H}$ and ${ }^{13} \mathrm{C}$ NMR, FTIR, single crystal XRD and DFT studies. These ligands acted very efficiently as co-catalysts for palladium acetate in Heck-Mizoroki cross coupling reactions. These ligand systems are useful addition in the field of electron donor ligands such as NHC and phosphines that can stabilize palladium in different oxidation states during $\mathrm{C}-\mathrm{C}$ coupling reactions.

\section{Conflicts of interest}

There are no conflicts of interest among authors to declare.

\section{Acknowledgements}

The authors gratefully acknowledged Higher Education Commission (HEC) Pakistan for research funding.

\section{References}

1 K. P. Butin, E. K. Beloglazkina and N. V. Zyk, Russ. Chem. Rev., 2005, 74, 531-553. 
2 S. Blanchard, E. Derat, E. M. Desage, F. L. Marine, M. Malacria and M. V. Mouriès, Eur. J. Inorg. Chem., 2012, 3, 376-389.

3 P. A. Schauer, Eur. J. Inorg. Chem., 2012, 3, 390-411.

4 L. A. Berben, de. B. Bruin and A. F. Heyduk, Chem. Commun., 2015, 51, 1553-1554.

5 K. A. Kreisel, G. P. A. Yap and K. H. Theopold, Eur. J. Inorg. Chem., 2012, 3, 520-529.

6 C. Costentin, J. M. Savéant and C. Tard, Proc. Natl. Acad. Sci. U.S.A., 2018, 115(37), 9104-9109.

7 K. Hindson and de. B. Bruin, Eur. J. Inorg. Chem., 2012, 3, 340-342.

8 M. E. Keary and Y. Jin-Quan, J. Org. Chem., 2013, 78, 89278955.

9 K. D. Vogiatzis, M. V. Polynski, J. K. Kirkland, J. Townsend, A. Hashemi, C. Liu and E. A. Pidko, Chem. Rev., 2019, 119, 2453-2523.

10 Q. Shi, R. J. Thatcher, J. Slattery, P. S. Sauari, A. C. Whitwood, P. C. McGowan and R. E. Douthwaite, Chem, 2009, 15, 11346-11360.

11 E. A. B. Kantchev, C. J. O'Brien and M. G. Organ, Angew. Chem., 2007, 46, 2768-2813.

12 E. J. Peris, Chem. Rev., 2018, 118, 9988-10031.

13 A. Krüger and M. Albrecht, Aust. J. Chem., 2011, 64, 11131117.

14 E. Peris, Chem. Rev., 2018, 118, 9988-10031.

15 N. Miquel, L. Mo, M. B. Helge, B. Stefan and A. Martin, Chem.-Eur. J., 2016, 22, 6740-6760.

16 Z. C. Duan, L. G. Wei, J. H. Chuan, C. D. Zheng and P. H. Xiang, Adv. Synth. Catal., 2008, 350, 1979-1983.

17 W. A. Herrmann, W. P. W. Bohm and C. W. K. Gstottmayr, J. Org. Chem., 2001, 617, 616-628.

18 N. Gürbüz, G. U. Z. Emine, O. K. Ismail, O. I. Bekir and C. E. T. Inkaya, Turk. J. Chem., 2015, 39, 1115-1157.

19 S. Johansson, C. C. Kitching, M. O. Colacot and T. J. V. Snieckus, Angew. Chem., 2012, 51, 5062-5085.

20 J. K. Stille, Angew. Chem., 1986, 25, 508-524.

21 C. P. Ruiz and S. L. Buchwald, Chem. Rev., 2016, 116, 1256412649.

22 M. S. Viciu, R. F. Germaneau, F. O. Navarro, E. D. Stevens and S. P. Nolan, Organometallics, 2002, 21, 5470-5472.

23 R. M. P. Veenboer, D. Gasperini, F. Nahra, D. B. Cordes, A. M. Z. Slawin and C. S. J. Cazin, Organometallics, 2002, 21, 5470-5472.

24 L. Melzig, A. Metzger and P. Knochel, Chem, 2011, 17, 29482956.

25 S. J. Sabounchei and A. Hashemi, Inorg. Chem. Commun., 2014, 47, 123-127.

26 M. Zafar, S. Zahra, M. Tahir, E. Mughal, M. Nazar and H. Rafique, Turk. J. Chem., 2018, 42, 63-74.

27 S. K. Schneider, G. R. Julius, C. Loschen, H. G. Raubenheimer, G. Frenking and W. A. Herrmann, Dalton Trans., 2006, 9, 1226-1233.
28 G. Khoroshilov, I. Demchak and T. Saraeva, Synthesis, 2008, 10, 1541-1544.

29 S. Crosignani, J. Gonzalez and D. Swinnen, Org. Lett., 2004, 6, 4579-4582.

30 L. P. Donald, M. L. Gary, S. K. George and A. V. James, Introduction to spectroscopy, Cengage Learning, 4th edn, 2008.

31 P. D. Boyd, W. Wright, L. James and M. N. Zafar, J. Mol. Struct., 2017, 1137, 84-96.

32 D. Yonchev, M. Vogt, D. Stumpfe, R. Kunimoto, T. Miyao and J. Bajorath, ACS Omega, 2018, 3(11), 15799-15808, software used: Molecular Operating Environment (MOE), version 2014.09; Chemical Computing Group ULC: 1010 Sherbooke St. West, Montreal, QC, Canada, 2018.

33 R. Mahbouband and S. Louhib, Int. Lett. Chem., Phys. Astron., 2016, 64, 34-44.

34 K. Senthilkumar and P. Kolandaivel, Comput. Biol. Chem., 2003, 27, 173-183.

35 M. Jafari, M. Salehi, M. Kubicki, A. Arab and A. Khaleghian, Inorg. Chim. Acta, 2017, 462, 329-335.

36 A. Arab and M. Habibzadeh, Comput. Theor. Chem., 2015, 1068, 52-56.

37 Z. Chang-Guo, A. N. Jeffrey and A. D. David, J. Phys. Chem. A, 2003, 20, 4184-4195.

38 Y. Kang, S. H. Jeon, Y. Cho and S. Han, Phys. Rev. B: Condens. Matter Mater. Phys., 2016, 93, 035131-035137.

39 C. Cappelli, C. Duce, M. Formica, V. Fusi, L. Ghezzi, L. Giorgi, M. Micheloni, P. Paoli, P. Rossi and T. M. Rosaria, Inorg. Chem., 2014, 417, 230-238.

40 R. F. Heck and J. J. Nolley, J. Org. Chem., 1972, 37, 2320-2322. 41 H. M. Lee and S. P. Nolan, Org. Lett., 2000, 2, 2053-2055.

42 V. Polshettiwar and Á. Molnár, Tetrahedron, 2007, 63, 69496976.

43 A. Tskhovrebov, K. Luzyanin, M. Haukka and K. V. Yu, J. Chem. Crystallogr., 2012, 42, 1170-1175.

44 I. P. Beletskaya and A. V. Cheprakov, Chem. Rev., 2000, 100(8), 3009-3066.

45 (a) T. M. Shaikh and F. E. Hong, Beilstein J. Org. Chem., 2013, 9, 1578-1588; (b) H.-J. Xu, Y.-Q. Zhao and X.-F. Zhou, J. Org. Chem., 2011, 76, 8036-8041; (c) K. Bahrami and S. N. Kamrani, Appl. Organomet. Chem., 2018, 32, e41024111; (d) C. Gnad, O. Dachwald, G. Raudaschl-Sieber and K. Köhler, J. Catal., 2019, 375, 257-266; (e) A. Nuri, Y. Mansoori and A. Bezaatpour, Appl. Organomet. Chem., 2019, 33, e4904-4919; (f) M. L. Kantam, P. Srinivas, J. Yadav, P. R. Likhar and S. Bhargava, J. Org. Chem., 2009, 74, 4882-4885; $(g)$ K. R. Balinge and P. R. Bhagat, Inorg. Chim. Acta, 2019, 495, 119017-119022; (h) M. M. Khodae and M. Dehghan, Appl. Organomet. Chem., 2019, 33, e46184627; (i) A. R. Hajipour, M. K. Tarrari and S. Jajarmi, Appl. Organomet. Chem., 2017, e4171-4179; (j) Z. Wang, X. Feng, W. Fang and T. Tu, Synlett, 2011, 7, 0951-0954. 